\title{
Extrusion Process as an Alternative to Improve Pulses Products Consumption. A Review
}

\author{
Mario Cotacallapa-Sucapuca $\left.{ }^{1,2,+}{ }^{(}\right)$, Erika N. Vega ${ }^{1,+}$, Helayne A. Maieves ${ }^{1,3} \mathbb{C}^{\oplus}$, José De J. Berrios ${ }^{4}{ }^{(}$, \\ Patricia Morales $^{1}$ (D), Virginia Fernández-Ruiz ${ }^{1}$ id and Montaña Cámara ${ }^{1, *} \mathbb{D}$ \\ 1 Nutrition and Food Science Department, Pharmacy Faculty, Complutense University of Madrid (UCM), Plaza \\ Ramón y Cajal s/n, E-28040 Madrid, Spain; mariocot@ucm.es (M.C.-S.); erimavega@gmail.com (E.N.V.); \\ helaynemaieves@gmail.com (H.A.M.); patricia.morales@farm.ucm.es (P.M.); vfernand@farm.ucm.es (V.F.-R.) \\ 2 Escuela Profesional de Ingeniería Agroindustrial, Universidad Nacional de Moquegua, Prolongación Calle \\ Ancash s/n, Moquegua 18001, Peru \\ 3 Faculdade de Nutrição, Universidade Federal de Pelotas, Rua Gomes Carneiro n ${ }^{\circ} 01$, \\ Pelotas 96010-610, RS, Brazil \\ 4 E USDA-ARS-WRRC, 800 Buchanan Street, Albany, CA 94710-1105, USA; jose.berrios@usda.gov \\ * Correspondence: mcamara@ucm.es; Tel./Fax: +34-913-941-799 \\ + Both (These) authors contributed equally to this work.
}

check for updates

Citation: Cotacallapa-Sucapuca, M.; Vega, E.N.; Maieves, H.A.; Berrios, J.D.J.; Morales, P.; Fernández-Ruiz, V.; Cámara, M. Extrusion Process as an Alternative to Improve Pulses Products Consumption. A Review. Foods 2021, 10, 1096. https:/ /doi.org/ $10.3390 /$ foods10051096

\section{Academic Editor:}

Antonella Pasqualone

Received: 20 April 2021

Accepted: 11 May 2021

Published: 15 May 2021

Publisher's Note: MDPI stays neutral with regard to jurisdictional claims in published maps and institutional affiliations.

Copyright: (c) 2021 by the authors. Licensee MDPI, Basel, Switzerland. This article is an open access article distributed under the terms and conditions of the Creative Commons Attribution (CC BY) license (https:// creativecommons.org/licenses/by/ $4.0 /)$

\begin{abstract}
The development of new food products obtained by extrusion processing has increased in recent years. Extrusion is used by the food industry to produce a wide variety of food products, such as ready-to-eat foods (e.g., snacks), among others. Pulses have also gained popularity as novel food ingredients in the formulation of a variety of food and food products, due to their high content of macro and micronutrients, and bioactive compounds that improve the nutritional and functional properties of the final food products. In this review, the impact of extrusion variables on proteins, carbohydrates, vitamins, phenolics and antinutritional compounds in pulses and pulsebased formulations are highlighted. Particularly, the impact of the specific mechanical energy. Also, the preservation, increase and/or reduction in those functional compounds, as a consequence of different extrusion processing conditions, are discussed.
\end{abstract}

Keywords: extrusion process; pulses; nutritional compounds; phytochemicals

\section{Introduction}

Extrusion (from the Latin word "extrudere") means the action of pushing/forcing something out [1,2]. Currently, extrusion is regarded as a high-temperature short-time (HTST), versatile and modern food operation that converts agricultural commodities, usually in a granular or powdered form, into fully cooked food products [3]. It is a continuous processing technology that combines multiple unit operations such as transportation and compression, mixing, shearing, plasticizing, melting, cooking, denaturation, fragmentation, texturization, shaping, reactive extrusion, functionalization, separation, etc., in one single machine [4,5]. The unit operations carried out in the extruder are generated by one or two Archimedes screws rotating into the barrel, which induce thermal and mechanical stress to the feed material under processing, which promotes physical and chemical changes, and forces the product to flow through a small orifice, called "die" [4,6]. The promoted physical and chemical changes to the feed material involve complex changes in the food matrix, phytochemical composition and organoleptic properties, such as texture, colour and flavour $[7,8]$.

One big advantage of the extrusion process is the capability to produce a wide range of finished food products with minimum processing time, using inexpensive raw material [3,9]. For this reason, extrusion is used by the food industry to produce a wide variety of highly consumed food products, such as some ready-to-eat food products or snacks [10-13]. These food products are traditionally based on starch raw materials, such 
as cereals and pseudocereals, since starch provides a cohesive mass that holds food components together [14].

Pulses are a type of leguminous crop. The Food and Agricultural Organization (FAO) defines "pulses" as those leguminous seeds harvested as dry grains; therefore, those leguminous seeds consumed as fresh vegetables (green peas, green beans, etc.), those mainly used for oil extraction (soybean and peanuts), and those crops used solely for sowing purposes (seeds of clover and alfalfa) are not considered "pulses" under the FAO definition [15]. Pulses represent an important source of gluten-free food for a healthy diet since they are an excellent source of protein, dietary fibre, minerals and vitamins. The world's food production is estimated to increase by $70 \%$ due to an expected large increase in the world's population. This food production increase would represent an increase of over 200 million tons of meat [16]. The increased consumption of meat has been recognized in several studies as a risk factor of common diseases such as type II diabetes, hypertension, dyslipidaemia, obesity and other cardiovascular diseases [17-20]. Pulses are recognized as a food with nutritional benefits and environmentally friendly crops, so their consumption should be encouraged in a daily diet. Based on the important contributions of pulses to the diet and the environment worldwide, the United Nations General Assembly (UNGA) declared 2016 as the International Year of Pulses [21].

The use of pulses as a healthy food source has been also recognized by the European Food Safety Authority [22], Agencia Española de Seguridad Alimentaria y Nutrición [23], U.S. Dietary Guidelines, National Heart [24], National Heart, Lung and Blood Institute [25], among other well-known institutions. They have recommended including pulses at least once a week in our diets, especially in substitution of animal protein, since the consumption of pulses four or more times a week were related with a $22 \%$ lower risk of coronary heart diseases and $11 \%$ of cardiovascular diseases $[26,27]$.

Beans are the most consumed pulses around the world, followed by chickpeas and lentils $[28,29]$. Consequently, beans are also the highest produced pulses in the world, with $28,902,672$ tonnes in 2019 , followed by chickpeas with 14,246,295 tonnes, dry cowpea with $8,903,329$ and lentil with 5,734,201 tonnes [30].

Review articles, such as Pasqualone et al. [31], have been published on the use of legumes in extruded products and the benefit of some extrusion parameters in the final products. The present review is aimed to relate the findings on the processing of pulses through extrusion technology as an interesting culinary process that improves the nutritional, functional and acceptability of pulses' products. It also aims to describe the importance of extruded parameters, such as the specific mechanical energy and its impact on the final food products quality. Additionally, it gives a comprehensive and detailed compilation of the effects of extrusion on pulses' macro and micronutrients, as water-soluble vitamins, and bioactive compounds.

\section{Food Extrusion Process and Variables}

The extrusion process involves many operational variables, such as barrel temperature, moisture content, screw speed and feed rate, etc. [32]. Combinations of different temperatures, pressures, and moisture may be used to create an unlimited range of product characteristics. For example, the density of individual pieces of an extrudate depends on the different pressure applied across the die [33]. The effects of the extrusion process parameters (temperature, screw speed, feed rate, screw configuration, die pressure and torque) and the raw material properties (e.g., proportion of ingredients, particle size, moisture content) on the quality of the extruded products have been studied by several researchers [34].

The structure of the extruded foods is a challenging scientific matter that has important implications for the food industry. Despite the significant progress in the modelling of the material flow in extruders and knowledge about the mechanical properties of cellular solid foods, the production of extruded foods with a targeted structure still relies on a trial-and-error approach. There is still no mechanical model capable of fully accounting for 
the influence of extrusion variables and material properties on expansion and final cellular structure [35].

Some important extruded parameters will be discussed afterwards to elucidate their impact on the final food products.

\subsection{Specific Mechanical Energy (SME)}

SME is a scale-independent measure of the mechanical energy dissipated as heat inside the material under extrusion. SME has been defined by some authors as the amount of mechanical energy or work input from the driver motor into the raw material being extruded, which is produced due to the friction generated between the screw and the product $[11,36,37]$. SME is a system parameter of the extrusion process used to try to establish a relationship between the processing variables and the properties of expanded extrudates, such as density, expansion ratio, solubility and degree of gelatinization.

The process parameters of the feed moisture, screw speed, barrel temperature and raw material properties have a great effect on the SME. Therefore, SME provides a good characterization of the extrusion process [11].

Once the raw material is introduced into the barrel, it is subjected to the rotational motion of the screw(s) and compacted, and submitted to more or less intense shear according to the screw geometry and rotation speed. SME has been used to evaluate the work exerted by the screw on the food matrix.

\subsection{Mechanism of Specific Mechanical Energy}

In a typical extrusion cooking process, the main processing variables considered are the ingredient feed rate (FR), water addition (WA), screw speed (SS) and barrel temperature (BT). While the variables generated by the process are barrel melt moisture content (MC) calculated from the WA and feed moisture (FM), percentage motor power consumed as indicated by the motor load (ML), pressure at the die (DP), and the product melt temperature (TM). Therefore, the extrusion cooking process can be viewed as a 4 -input $x$ 4-output process, from a systems perspective [38].

Other authors concurred that the food extrusion process involves multiple input and output systems resulting in complex interactions [39]. To facilitate system identification for the subsequent control design, it is desirable to reduce the dimensionality of the system to be controlled. Since the variables desirable to be controlled in a product (chemical) are strongly related to the process (physical) variables that can be controlled, it is necessary to find a correlation matrix between the product variables and the process variables. To simplify the multiplicity of the variables, the use of SME as the main process variable has been proposed [40].

A systematic analysis of the extrusion process of puffed corn snack products revealed that the SME and screw speed (SS) were a desirable pairing of variables to measure and manipulate, respectively, for regulating the extrude density [38]. Other authors have indicated that an increase in the screw speed causes greater friction and shearing between the materials under extrusion, leading to an increase in SME [11]. Moreover, the SME dissipated during shearing is transformed into thermal energy, increasing the temperature of the material, and modifying the physical and chemical properties of the resulted extruded product [32]. This information indicates that SME is a good indicator of the degree of cooking in materials subjected to the extrusion process.

\section{Changes on Food Composition Due to Extrusion Process}

Extrusion is a thermo-mechanical process that induces many chemical and structural transformations in the phytochemical composition of the product, as complex formation between amylose and lipids, degradation reactions of vitamins and pigments, among others [41]. Extrusion has also the advantage of increasing protein and starch digestibility, solubilizing dietary fibre, inactivating thermolabile toxins and some antinutritional factors, as well as undesirable enzymes such as lipoxygenases and peroxidases [13,42]. Moreover, 
it was reported that some bioactive compounds, such as the total phenolic compounds and $\alpha$-galactosides were not greatly affected [42]. However, these results were highly conditioned by the extrusion conditions and percentage of the selected raw material in the mix, used as the feed material for extrusion [43,44].

\subsection{The Influence of Extrusion Process on Pulse Proteins}

Pulses are a good source of functional proteins. The most representative protein class is the globulins, which comprise around $70 \%$ of the total pulse's proteins, and according to their sedimentation coefficient can be categorized as $7 \mathrm{~S}$ and 11S, or vicilin and legumin, respectively.

The protein content in pulses varies from 17 to $30 \%$, which represents twice the value of the protein amount present in cereals. Moreover, pulse and cereal proteins are considered complementary, since pulses are rich in the amino acid lysine but relatively low in sulphur amino acids (methionine and cysteine), which are higher in cereals [44-46].

From the total pulse protein content, 4 to $20 \%$ are albumins that contain enzymatic proteins, such as protease inhibitors, amylase inhibitors, and lectins; while, prolamins and glutelins represent $1-3$ and $10-20 \%$ of the total protein, respectively [47]. Prolamins are characterized as having a high amount of proline and glutamine, while the glutelins are characterized for the presence of methionine and cysteine [45-49].

The high-temperature, shear, and stress conditions that the extrusion process imparts on the treated material promotes denaturation of the proteins, leading to the loss of their ternary and quaternary structure, a decrease in disulphide bonds and an increase in protein solubility [31,50-52].

Also, due to the high processing temperature and the natural presence of certain amino acids and sugars in the material, the Maillard reaction takes place, which significantly affects the characteristics of the products, particularly their colour, aroma, and nutritional value [53-55]. Additionally, another detrimental product of the Maillard reaction is acrylamide, which is classified as a group 2 a carcinogen. More specifically, acrylamide is produced mainly under conditions of high temperature and low moisture due to the reactions between the reducing sugars and asparagine. This reaction can also occur with other free amino acids, such as glutamine, arginine, cysteine, and aspartic acid, but in those cases only traces of acrylamide were determined [56,57]. To minimize the acrylamide formation in the material under extrusion, an increase in feed moisture or the injection of $\mathrm{CO}_{2}$ during processing can promote a gradual decrease in the acrylamide content in the extrudate. Other reported potential strategies to reduce the acrylamide content in extruded products are the addition of amino acids, such as cysteine or lysine, asparaginase enzyme, the control of processing temperatures, or the addition of pulses [56,58]. Galani et al. [59] observed that the inclusion of chickpea in cereal-base formulations, heated at $160{ }^{\circ} \mathrm{C}$ for $20 \mathrm{~min}$, reduced acrylamide formation while it improved the nutritional value of the formulated flours. Moreover, Tuncel et al. [60] reported that the addition of $5 \%$ of pea flour to a bread formulation containing wheat bran and whole bran, resulted in a decrease of $57 \%$ and $68 \%$ in the acrylamide levels.

Various authors highlight that extrusion technology is an effective processes to improve the protein quality and digestibility of pulses and pulse-based extrudates. Table 1 summarises the most relevant studies of the effect of extrusion conditions on the protein content of pulse extrudates.

High extrusion temperature conditions were reported to have the effect of decreasing the amount of protein in different extruded pulses (peas, chickpeas, faba beans and kidney beans), at barrel temperatures over $180^{\circ} \mathrm{C}$; while no significant changes were observed at barrel temperatures close to $140^{\circ} \mathrm{C}[61,62]$. Most importantly, extrusion cooking had a positive effect on pulse extrudates by improving their water solubility and water absorption indexes, inactivating antinutritional components, and increasing their protein digestibility. Therefore, the resulted improved pulse extrudates were considered adequate to be added as a functional ingredient (usually in powder form) in the preparation of bread, soups, and creams [61-63]. 
When comparing extrusion, traditional cooking, and baking technologies in the processing of different types of beans and lentils, extrusion technology was most effective to preserve the protein content in the final product. Extrusion also improved their protein solubility and in vitro digestibility. Additionally, extrusion promoted an increase in amino acid content, particularly those sulphur-containing amino acids. The reported findings allowed to conclude that the extrusion process is a suitable process to improve amino acid availability and protein digestibility $[64,65]$. It has been demonstrated that protein denaturation and a reduction in enzyme inhibitors, due to extrusion processing, improved the digestibility of proteins. However, the extent of the improvement depended on the food matrix and the type of pulses under consideration, among other parameters $[63,66]$

Table 1. Effect of different extrusion processing conditions on the protein content of pulses and pulse-based extrudates.

\begin{tabular}{|c|c|c|c|c|}
\hline Food Matrix & Extrusion Conditions & $\begin{array}{l}\text { Effect: In the } \\
\text { Amount }\end{array}$ & $\begin{array}{l}\text { Effect: Protein In } \\
\text { Vitro Digestibility }\end{array}$ & Reference \\
\hline \multirow{5}{*}{$\begin{array}{l}\text { Faba bean } \\
\text { (Vicia faba L.) }\end{array}$} & Single; ss: $250 \mathrm{rpm} ; \mathrm{bt}: 140{ }^{\circ} \mathrm{C}$; m: $18 \%$; & Insignificant & Increase in vitro & \multirow{3}{*}[61]{} \\
\hline & $\begin{array}{c}\text { Single; ss: } 250 \mathrm{rpm} ; \mathrm{bt}: 180^{\circ} \mathrm{C} ; \mathrm{m}: 18 \% \text {; } \\
\mathrm{ft}: 100{ }^{\circ} \mathrm{C} ; \mathrm{sc}: 4: 1\end{array}$ & $\begin{array}{l}\text { Insignificant } \\
\text { decrease }\end{array}$ & Increase in vitro & \\
\hline & $\begin{array}{c}\text { Single; ss: } 250 \mathrm{rpm} ; \mathrm{bt}: 140{ }^{\circ} \mathrm{C} ; \mathrm{m}: 22 \% \\
\mathrm{ft}: 10{ }^{\circ} \mathrm{C} ; \mathrm{sc}: 4: 1\end{array}$ & $\begin{array}{l}\text { Insignificant } \\
\text { decrease }\end{array}$ & Increase in vitro & \\
\hline & $\begin{array}{c}\text { Single; ss: } 250 \mathrm{rpm} ; \mathrm{bt}: 180{ }^{\circ} \mathrm{C} \text {; m: } 22 \% \text {; } \\
\text { ft: } 100{ }^{\circ} \mathrm{C} ; \mathrm{sc}: 4: 1\end{array}$ & $\begin{array}{l}\text { Significative } \\
\text { decrease }\end{array}$ & Increase in vitro & \multirow[b]{2}{*}{ [64] } \\
\hline & $\begin{array}{c}\text { Twin; ss: } 400-600 \mathrm{rpm} ; \mathrm{bt}: 30-50{ }^{\circ} \mathrm{C} \\
70-90^{\circ} \mathrm{C} \text { and } 100-120^{\circ} \mathrm{C} ; \\
\text { m: } 0.7-1.2 \mathrm{~kg} / \mathrm{h} \text { liquid feed rate }\end{array}$ & Small increase & High improvement & \\
\hline \multirow{3}{*}{$\begin{array}{c}\text { Pea seeds } \\
\text { (Pisum sativum L.) }\end{array}$} & $\begin{array}{c}\text { Single; ss: } 250 \mathrm{rpm} ; \mathrm{bt}: 140{ }^{\circ} \mathrm{C} ; \mathrm{m}: 18 \% \\
\mathrm{ft}: 100{ }^{\circ} \mathrm{C} ; \mathrm{sc}: 4: 1\end{array}$ & $\begin{array}{l}\text { Insignificant } \\
\text { decrease }\end{array}$ & Increase in vitro & \multirow{8}{*}[61]{} \\
\hline & $\begin{array}{c}\text { Single; ss: } 250 \mathrm{rpm} ; \mathrm{bt}: 180^{\circ} \mathrm{C} ; \mathrm{m}: 18 \% \text {; } \\
\text { ft: } 100{ }^{\circ} \mathrm{C} ; \mathrm{sc}: 4: 1\end{array}$ & Significant decrease & Increase in vitro & \\
\hline & $\begin{array}{c}\text { Single; ss: } 250 \mathrm{rpm} ; \mathrm{bt}: 140^{\circ} \mathrm{C} ; \mathrm{m}: 22 \% \\
\text { ft: } 100{ }^{\circ} \mathrm{C} ; \mathrm{sc}: 4: 1\end{array}$ & $\begin{array}{l}\text { Insignificant } \\
\text { decrease }\end{array}$ & Increase in vitro & \\
\hline \multirow{5}{*}{$\begin{array}{c}\text { Chickpeas } \\
\text { (Cicer arietinum L.) }\end{array}$} & $\begin{array}{c}\text { Single; ss: } 250 \mathrm{rpm} ; \mathrm{bt}: 180^{\circ} \mathrm{C} \mathrm{m:} 22 \% \text {; } \\
\mathrm{ft}: 100^{\circ} \mathrm{C} ; \mathrm{sc}: 4: 1\end{array}$ & Significant decrease & Increase in vitro & \\
\hline & $\begin{array}{c}\text { Single; ss: } 250 \mathrm{rpm} \text {; bt: } 140^{\circ} \mathrm{C} \text {; m: } 18 \% \text {; } \\
\text { ft: } 100{ }^{\circ} \mathrm{C} ; \mathrm{sc}: 4: 1\end{array}$ & $\begin{array}{l}\text { Insignificant } \\
\text { decrease }\end{array}$ & Increase in vitro & \\
\hline & $\begin{array}{c}\text { Single; ss: } 250 \mathrm{rpm} ; \mathrm{bt}: 180^{\circ} \mathrm{C} ; \mathrm{m}: 18 \% \\
\mathrm{ft}: 10{ }^{\circ} \mathrm{C} ; \mathrm{sc}: 4: 1\end{array}$ & $\begin{array}{l}\text { Insignificant } \\
\text { decrease }\end{array}$ & Increase in vitro & \\
\hline & $\begin{array}{c}\text { Single; ss: } 250 \mathrm{rpm} ; \mathrm{bt}: 140^{\circ} \mathrm{C} ; \mathrm{m}: 22 \% \\
\mathrm{ft}: 100{ }^{\circ} \mathrm{C} ; \mathrm{sc}: 4: 1\end{array}$ & $\begin{array}{l}\text { Insignificant } \\
\text { decrease }\end{array}$ & Increase in vitro & \\
\hline & $\begin{array}{l}\text { Single; ss: } 250 \mathrm{rpm} ; \mathrm{bt}: 180^{\circ} \mathrm{C} ; \mathrm{m}: 22 \% \text {; } \\
\text { ft: } 100^{\circ} \mathrm{C} \text {; sc: } 4: 1\end{array}$ & $\begin{array}{l}\text { Insignificant } \\
\text { decrease }\end{array}$ & Increase in vitro & \\
\hline $\begin{array}{l}\text { Chickpea }+40 \% \\
\text { barley bland }\end{array}$ & $\begin{array}{l}\text { Twin; ss: } 320 \text { rpm; bt: } 150,160{ }^{\circ} \mathrm{C} \text {; } \\
\text { m: } 18 \%\end{array}$ & \multicolumn{2}{|c|}{$\begin{array}{l}\text { The higher the temperature, the higher was the } \\
\text { increase in the amount of protein digestibility }\end{array}$} & [67] \\
\hline \multirow{4}{*}{$\begin{array}{l}\text { Kidney beans } \\
\text { (Phaseolus vulgaris L.) }\end{array}$} & $\begin{array}{c}\text { Single; ss: } 250 \mathrm{rpm} ; \mathrm{bt}: 140{ }^{\circ} \mathrm{C} ; \mathrm{m}: 18 \% \\
\mathrm{ft}: 10{ }^{\circ} \mathrm{C} ; \mathrm{sc}: 4: 1\end{array}$ & $\begin{array}{c}\text { Insignificant } \\
\text { decrease }\end{array}$ & Increase in vitro & \multirow{4}{*}[61]{} \\
\hline & $\begin{array}{c}\text { Single; ss: } 250 \mathrm{rpm} ; \mathrm{bt}: 180{ }^{\circ} \mathrm{C} ; \mathrm{m}: 18 \% \\
\text { ft: } 100{ }^{\circ} \mathrm{C} ; \mathrm{sc}: 4: 1\end{array}$ & Significant decrease & Increase in vitro & \\
\hline & $\begin{array}{c}\text { Single; ss: } 250 \mathrm{rpm} ; \mathrm{bt}: 140{ }^{\circ} \mathrm{C} ; \mathrm{m}: 22 \% \text {; } \\
\mathrm{ft}: 100^{\circ} \mathrm{C} ; \mathrm{sc}: 4: 1\end{array}$ & $\begin{array}{l}\text { Insignificant } \\
\text { decrease }\end{array}$ & Increase in vitro & \\
\hline & $\begin{array}{c}\text { Single; ss: } 250 \mathrm{rpm} ; \mathrm{bt}: 180^{\circ} \mathrm{C} ; \mathrm{m}: 22 \% \text {; } \\
\text { ft: } 100^{\circ} \mathrm{C} \text {; sc: } 4: 1\end{array}$ & $\begin{array}{l}\text { Insignificant } \\
\text { decrease }\end{array}$ & Increase in vitro & \\
\hline $\begin{array}{l}\text { Kidney bean carioca } \\
\text { (pontal) }\end{array}$ & $\begin{array}{c}\text { Single ss: } 150 \text { rpm; bt: } 150{ }^{\circ} \mathrm{C} ; \mathrm{m}: 20 \% \\
\text { cr: } 3: 1\end{array}$ & $\begin{array}{l}\text { Insignificant } \\
\text { increase }\end{array}$ & $\begin{array}{l}\text { Increase in vitro } \\
\quad(72.3 \%)\end{array}$ & \multirow[t]{2}{*}{ [63] } \\
\hline $\begin{array}{l}\text { Kidney bean black } \\
\text { (grafite) }\end{array}$ & $\begin{array}{c}\text { Single; ss: } 150 \text { rpm; bt: } 150{ }^{\circ} \mathrm{C} ; \mathrm{m}: 20 \% \\
\text { cr: } 3: 1\end{array}$ & $\begin{array}{l}\text { Insignificant } \\
\text { increase }\end{array}$ & $\begin{array}{l}\text { Increase in vitro } \\
\quad(84.5 \%)\end{array}$ & \\
\hline
\end{tabular}


Table 1. Cont.

\begin{tabular}{|c|c|c|c|c|}
\hline Food Matrix & Extrusion Conditions & $\begin{array}{l}\text { Effect: In the } \\
\text { Amount }\end{array}$ & $\begin{array}{l}\text { Effect: Protein In } \\
\text { Vitro Digestibility }\end{array}$ & Reference \\
\hline Kidney bean black & $\begin{array}{c}\text { Twin; ss: } 400-600 \mathrm{rpm} ; \mathrm{bt}: 30-50{ }^{\circ} \mathrm{C}, \\
70-90{ }^{\circ} \mathrm{C} \text { and } 100 / 120{ }^{\circ} \mathrm{C} ; \\
0.7-1.2 \mathrm{~kg} / \mathrm{h} \text { liquid feed rate }\end{array}$ & $\begin{array}{l}\text { Insignificant } \\
\text { increase }\end{array}$ & $\begin{array}{l}\text { Increase in the true and } \\
\text { in vitro }\end{array}$ & \multirow{4}{*}{ [64] } \\
\hline Kidney bean navy & $\begin{array}{c}\text { Twin; ss: } 400-600 \mathrm{rpm} ; \mathrm{bt}: 30-50{ }^{\circ} \mathrm{C}, \\
70-90{ }^{\circ} \mathrm{C} \text { and } 100 / 120{ }^{\circ} \mathrm{C} ; \\
0.7-1.2 \mathrm{~kg} / \mathrm{h} \text { liquid feed rate }\end{array}$ & $\begin{array}{l}\text { Insignificant } \\
\text { increase }\end{array}$ & $\begin{array}{l}\text { Increase in the true and } \\
\text { in vitro }\end{array}$ & \\
\hline Kidney bean pinto & $\begin{array}{c}\text { Twin; ss: } 400-600 \mathrm{rpm} ; \mathrm{bt}: 30-50{ }^{\circ} \mathrm{C}, \\
70-90{ }^{\circ} \mathrm{C} \text { and } 100 / 120^{\circ} \mathrm{C} ; \\
0.7-1.2 \mathrm{~kg} / \mathrm{h} \text { liquid feed rate }\end{array}$ & $\begin{array}{l}\text { Insignificant } \\
\text { increase }\end{array}$ & $\begin{array}{l}\text { Improvement in the } \\
\text { true and in vitro }\end{array}$ & \\
\hline Red kidney bean & $\begin{array}{c}\text { Twin; ss: } 400-600 \mathrm{rpm} ; \mathrm{bt}: 30-50{ }^{\circ} \mathrm{C}, \\
70-90{ }^{\circ} \mathrm{C} \text { and } 100 / 120{ }^{\circ} \mathrm{C} ; \\
0.7-1.2 \mathrm{~kg} / \mathrm{h} \text { liquid feed rate }\end{array}$ & $\begin{array}{l}\text { Insignificant } \\
\text { increase }\end{array}$ & $\begin{array}{l}\text { Improvement in the } \\
\text { true and in vitro }\end{array}$ & \\
\hline $\begin{array}{c}\text { Rice }(80-60 \%) \\
\text { kidney bean } \\
\text { (Phaseolus vulgaris L.) } \\
(20-40 \%)\end{array}$ & $\begin{array}{c}\text { Twin; ss: } 900-950 \mathrm{rpm} ; \mathrm{bt}: 125^{\circ} \mathrm{C} ; \\
\text { m: } 2.5-3.2 \mathrm{~kg} / \mathrm{h}\end{array}$ & Small increase & Great improvement & [10] \\
\hline $\begin{array}{l}\text { Red lentil (Lens } \\
\text { culinaris L.) } \\
\text { Green lentil (Lens } \\
\text { culinaris L.) }\end{array}$ & $\begin{array}{l}\text { Twin; ss: } 650 \mathrm{rpm} \text {; bt: } 30-50{ }^{\circ} \mathrm{C}, \\
70-90^{\circ} \mathrm{C} \text { and } 100-120{ }^{\circ} \mathrm{C} ; \mathrm{m}: 0.8 \mathrm{~kg} / \mathrm{h} \\
\text { Twin; ss: } 650 \mathrm{rpm} \text {; bt: } 30-50{ }^{\circ} \mathrm{C}, \\
70-90^{\circ} \mathrm{C} \text { and } 100-120{ }^{\circ} \mathrm{C} ; \mathrm{m}: 0.8 \mathrm{~kg} / \mathrm{h}\end{array}$ & $\begin{array}{l}\text { Small increase } \\
\text { Small increase }\end{array}$ & $\begin{array}{l}\text { Improvement in the } \\
\text { true and in vitro } \\
\text { Improvement in the } \\
\text { true and in vitro }\end{array}$ & {$[65]$} \\
\hline
\end{tabular}

Twin or single: type of screw; ss: screw speed; bt: barrel temperature; ft: feed temperature; m: moisture; cr: compression ratio.

The use of different food ingredient sources to develop acceptable and quality extruded products has been the focus of the most recent investigations. Arribas, et al. [43] reported the improvement of the nutritional quality of rice-based ready-to-eat food with bean and whole carob fruit (Ceratonia siliqua L.). They concluded that the developed extruded product had a balanced protein profile and improved protein digestibility, compared to the extruded product without bean addition.

The response surface methodology (RSM) has been used by some researchers to investigate the best conditions for product optimization of the extrusion process. Guldiken et al. [67], using RSM to optimize the extrusion process of a mixture of chickpea and barley flours (60:40), were able to obtain a product with great protein quality under the extrusion conditions of $160{ }^{\circ} \mathrm{C}$ barrel temperature, $18 \%$ feed moisture and $320 \mathrm{rpm}$ screw speed.

\subsection{Carbohydrates Content in Extruded Pulse Product}

Pulses contain between 60-65\% carbohydrates, a bit lower than in cereals, which contain between 70 and $80 \%$ [44]. The main storage carbohydrate in pulses is starch, and other carbohydrates found in pulses are monosaccharides (ribose, glucose, galactose, and fructose), disaccharides (sucrose and maltose), oligosaccharides (mostly $\alpha$-galactosides) and other polysaccharides $[3,12,27,68]$.

Starch is the main source of carbohydrate in the human diet. Starch represents 30$40 \%$ of the daily energy intake [69], and is one of the most available and economical organic food materials on Earth [70]. Starch granules are composed primarily of amylose and amylopectin, of which proportions vary depending on the cultivar botanical origin. The amylose/amylopectin ratio has been found to be a determinant of the functional properties of starch-based materials, such as mechanical properties, oxygen permeability, water binding capacity, gel property, viscosity etc., and gives starch its typical properties (solubility, cooking time, gelatinization, etc.) that determine the suitability of a type of starch for a particular final use $[10,71]$. Starch with an amylose/amylopectin ratio of approximately $1: 3$ or 1:4 provides a suitable ingredient to obtain expanded and crispy products [72]. 
A prerequisite for obtaining a cohesive dough is the presence of a gel former food ingredient. Therefore, in this regard, free amylose, pre-gelatinized starch, or pre-gelatinized waxy starch can be used as a gel former and promote a cohesive mass to improve the functional properties of the extruded products [14]. Additionally, some other authors have reported that modified starch or hydroxypropylated starch with a high amylose content produce films with a high mechanical strength, flexibility and transparency. They also indicated that the stability of hydroxypropylated starch was highly dependent on the amylose content [73].

Starch is an essential food ingredient widely used in food extrusion. During extrusion, the starch-water mixture becomes melted by solid friction, viscous dissipation and heat conduction, causing a dense material consisting of starch and protein. The dense material is then forced through a matrix where the water vapour trapped in the melt expands the material giving a porous structure, called solid foam [74]. The pore shape and volume in the foam is determined by the natural ability of amylose and amylopectin polymer chains to assemble into an organized supramolecular nanoscale lamellar structure, within the starch granule consisting of crystalline and amorphous regions [70]. The extrusion conditions of the temperature profile, shear rate, and residence time during treatment, influence simultaneously the starch behaviour and its properties. Moreover, several authors have reported that the effects of the starch structural properties and starch modification, during the extrusion treatment on the product properties, were monitored via die pressure, motor torque, mean residence time and specific mechanical energy (SME) [75]. This finding goes along with the report of Pardhi et al. [41] who indicated that during extrusion cooking, the starch undergoes many physical, chemical, and structural transformations.

Regarding the effect of the extrusion process on the carbohydrate fraction in pulses, variability in various results is reported. Several authors determined a significant increase in the total available content of carbohydrates after extrusion cooking, Cardoso-Santiago and Arêas [76] reported a significant increase of 5.4\% in chickpeas (200 rpm of single-screw extruder at $130{ }^{\circ} \mathrm{C}$ and $13 \%$ feed moisture). Alonso et al. [77] observed an increase of $1 \%$ and $3.2 \%$ in extruded samples of pea and kidney bean, respectively, after extrusionprocessing conditions of $100 \mathrm{rpm}$ screw speed, $25 \%$ moisture barrel and a temperature of $150{ }^{\circ} \mathrm{C}$. Morales et al. [78] reported a significant increase, around $5-17 \%$ in the extruded lentil flours processed on a twin-screw extruder at $160^{\circ} \mathrm{C}$ die temperature, $500 \mathrm{rpm}$ speed twin screw and $17 \%$ feed moisture. Arribas et al. [10] reported a 1 to $9 \%$ increase in the extrudates formulated with $20 \%$ beans and $5 \%$ whole carob, as well as with $40 \%$ beans with $10 \%$ whole carob, respectively, extruded at $125^{\circ} \mathrm{C}$ die temperature, $900-950 \mathrm{rpm}$ screw and $10.0-12.8 \%$ feed moisture. The determined increase may be due to an increase in the carbohydrate availability present inside the cell generated by the diffusion of the solvent inside the matrix, leading to a subsequent increase in the specific surface area trough cell rupture and higher cell wall porosity [78-80].

On the other hand, some authors reported a decrease in the amount of total carbohydrates. Berrios et al. [3] determined that the total available carbohydrates in the extruded lentil, chickpea and dry pea flours decreased in all the extruded flours compared to their corresponding raw counterpart. However, they also indicated that only the decrease in the total carbohydrates determined in the chickpea samples were considered significative. The temperature, moisture and screw speed conditions applied during extrusion are known to have major physicochemical modifications. Therefore, the reported decrease in the total carbohydrates may be explained by a macromolecular degradation of polysaccharides during processing, promoting the release of monosaccharides. Also, the extrusion process could have hydrolysed oligosaccharides, possibly through the breaking of the $2 \rightarrow 1$ furanosidic bonds in sucrose and raffinose, promoting the formation of lower molecular weight sugars. Likewise, the monosaccharides behaviour can also vary during processing, as is summarized in Table $2[3,81]$. 
Table 2. Effect of extrusion processing conditions on sugars of different pulse extrudates.

\begin{tabular}{|c|c|c|c|c|c|c|c|}
\hline \multirow{2}{*}{ Matrix } & \multirow{2}{*}{ Extrusion Conditions } & \multicolumn{5}{|c|}{ Sugars } & \multirow{2}{*}{ Reference } \\
\hline & & Sucrose & Maltose & Fructose & Galactose & Ribose & \\
\hline \multirow{2}{*}{$\begin{array}{c}\text { Bean (Phaseolus } \\
\text { vulgaris L.) }\end{array}$} & Non-Extruded & $20.8 \pm 0.05$ & $3.5 \pm 0.28$ * & - & $0.1 \pm 0.01$ & - & \multirow{4}{*}{ [81] } \\
\hline & $\begin{array}{l}\text { Twin, ss: } 200 \text { rpm; } \\
\text { bt: } 160^{\circ} \mathrm{C} ; \mathrm{m}: 20 \%\end{array}$ & $20.1 \pm 0.02$ & $4.2 \pm 0.24$ & - & $0.5 \pm 0.01$ & - & \\
\hline \multirow{2}{*}{$\begin{array}{c}\text { Bean (Phaseolus } \\
\text { vulgaris L.) }+0.4 \% \\
\mathrm{NaHCO}_{3}\end{array}$} & Non-Extruded & $19.2 \pm 0.10$ & $4.0 \pm 0.02$ & - & $0.6 \pm 0.01$ & - & \\
\hline & $\begin{array}{l}\text { Twin, ss: } 200 \text { rpm; } \\
\text { bt: } 160{ }^{\circ} \mathrm{C} ; \mathrm{m}: 20 \%\end{array}$ & $16.3 \pm 0.10$ & $3.5 \pm 0.11$ & - & $1.0 \pm 0.01$ & - & \\
\hline \multirow{2}{*}{$\begin{array}{l}\text { Dry pea (Pisum } \\
\text { sativum L.) }\end{array}$} & Non-Extruded & 6.47 & 1.91 & 1.24 & 7.22 & 5.21 & \multirow{6}{*}{ [3] } \\
\hline & $\begin{array}{l}\text { Twin; ss: } 500 \text { rpm; } \\
\text { bt: } 160^{\circ} \mathrm{C} ; \mathrm{m}: 17 \%\end{array}$ & 12.99 & n.d. & n.d. & n.d. & n.d. & \\
\hline \multirow{2}{*}{$\begin{array}{l}\text { Chickpea (Cicer } \\
\text { arietinum L.) }\end{array}$} & Non-Extruded & 7.94 & 01.68 & 1.56 & 1.84 & 0.58 & \\
\hline & $\begin{array}{l}\text { Twin; ss: } 500 \text { rpm; } \\
\text { bt: } 160^{\circ} \mathrm{C} ; \mathrm{m:}: 17 \%\end{array}$ & 10.03 & 01.77 & 1.45 & 0.66 & 0.62 & \\
\hline \multirow{2}{*}{$\begin{array}{c}\text { Lentil } \\
\text { (Lens culinaris L.) }\end{array}$} & Non-Extruded & 6.97 & 00.39 & 0.85 & n.d. & 3.05 & \\
\hline & $\begin{array}{l}\text { Twin; ss: } 500 \text { rpm; } \\
\text { bt: } 160{ }^{\circ} \mathrm{C} ; \mathrm{m}: 17 \%\end{array}$ & 6.01 & 01.33 & 1.03 & n.d. & 1.36 & \\
\hline \multirow{2}{*}{$\begin{array}{l}\text { Lentil (Lens culinaris } \\
\text { L. Medik) }\end{array}$} & Non-Extruded & $10.22 \pm 0.54$ & $3.09 \pm 0.18$ & - & - & - & \multirow[b]{2}{*}[12]{} \\
\hline & $\begin{array}{l}\text { Twin; ss: } 500 \text { rpm; } \\
\text { bt: } 160{ }^{\circ} \mathrm{C} ; \mathrm{m}: 17 \%\end{array}$ & $12.82 \pm 0.63$ & $5.51 \pm 0.46$ & - & - & - & \\
\hline \multirow{2}{*}{$\begin{array}{c}\text { Rice }(80 \%)+\text { Pea } \\
\text { (Pisum sativum L.) } \\
(20 \%)\end{array}$} & Non-Extruded & 4.76 & - & - & - & - & \multirow{4}{*}{ [82] } \\
\hline & $\begin{array}{c}\text { Twin; ss: } 900 \mathrm{rpm} ; \\
\text { bt: } 125^{\circ} \mathrm{C} ; \\
\text { m: } 2.50 \mathrm{~kg} / \mathrm{h}\end{array}$ & 9.44 & - & - & - & - & \\
\hline \multirow{2}{*}{$\begin{array}{c}\text { Rice }(60 \%)+\text { Pea } \\
\text { (Pisum satioum L.) } \\
(40 \%)\end{array}$} & Non-Extruded & 7.97 & - & - & - & - & \\
\hline & $\begin{array}{c}\text { Twin; ss: } 950 \mathrm{rpm} ; \\
\text { bt: } 125^{\circ} \mathrm{C} ; \\
\text { m: } 2.50 \mathrm{~kg} / \mathrm{h}\end{array}$ & 14.46 & - & - & - & - & \\
\hline \multirow{2}{*}{$\begin{array}{c}\text { Rice }(80 \%)+\text { Bean } \\
\text { (Phaseolus vulgaris L.) } \\
(20 \%)\end{array}$} & Non-Extruded & $8.65 \pm 0.15$ & - & - & - & - & \multirow{4}{*}{ [43] } \\
\hline & $\begin{array}{c}\text { Twin; ss: } 900 \mathrm{rpm} ; \\
\text { bt: } 125^{\circ} \mathrm{C} ; \\
\text { m: } 2.50 \mathrm{~kg} / \mathrm{h}\end{array}$ & $10.27 \pm 0.08$ & - & - & - & - & \\
\hline \multirow{2}{*}{$\begin{array}{c}\text { Rice }(60 \%)+\text { Bean } \\
\text { (Phaseolus vulgaris L.) } \\
(40 \%)\end{array}$} & Non-Extruded & $12.44 \pm 0.15$ & - & - & - & - & \\
\hline & $\begin{array}{c}\text { Twin; ss: } 950 \mathrm{rpm} ; \\
\text { bt: } 125^{\circ} \mathrm{C} ; \\
\text { m: } 2.50 \mathrm{~kg} / \mathrm{h}\end{array}$ & $17.84 \pm 0.16$ & - & - & - & - & \\
\hline
\end{tabular}

Values are expressed in $\mathrm{mg} / \mathrm{g} ;{ }^{*}$ maltose + inositol; twin or single: type of screw; ss: screw speed; bt: barrel temperature; m: moisture; n.d.: not detected.

\subsubsection{Dietary Fibre and Their Modification under Extrusion Process}

Currently, dietary fibre is defined as "food material, particularly plant material, that is not hydrolysed by enzymes secreted by the human digestive tract but that may be digested by microflora in the gut" [83]. Dietary fibre can be classified according to different criteria, as chemical, analytical, or physiological. However, the most generally accepted classification is based on their solubility in water systems under physiological conditions. Dietary fibre represents two groups of fibres, insoluble and soluble dietary fibre. Soluble dietary fibre (SDF) is readily fermented in the large intestine by the microflora, and it consists mostly of natural gel-forming fibres like pectins, gums, mucilages, inulin, fructans, some hemicelluloses and non-digestible oligosaccharides. Due to the ability of the forming gels, the addition of SDF can maximize the viscous characteristic of foods and delay the digestion time of nutrients. Insoluble dietary fibre (IDF) contributes to the promotion of the laxation effect, through the increase in faecal bulk. The main components of IDF are cellulose, some hemicellulose, lignin, arabinoxylan and resistant starch [27,84-87].

The amount of TDF in pulses varies between 3-30\% depending on different factors such as agronomic, genetic, seed maturation, and processing conditions. The amount of 
IDF represents the major fraction, which varies between 4 and $28 \%$ of the TDF $[85,88]$. In 2011, Oomah et al. [44] published a recompilation of six studies carried out between 1997 and 2003 where they reported DF contents of 23-32, 18-22, 18-20, 14-26 (\%) for bean, chickpea, lentil, and dry pea, respectively. Later, Cámara et al. [84,85] compiled and reported data of the DF content in pulses from different countries. They reported values of DF content ranging between 16.12 to $26.20,6.5$ to $29.80,20.35$ to 27.60 , and 3.31 to 29.70 $(\mathrm{g} / 100 \mathrm{~g})$, for chickpea, lentils, common beans, and dry green peas, respectively.

Resistant starches (RS) are starch molecules that resist digestion and in this sense, they function similarly to DF. Even though RS are not always included as part of the dietary fibre fractions in foods, their physical property behaviour is very similar to that exhibited by IDF. Studies indicated that RS is fermented in the gut, producing short-chain fatty acids (SCFAs) such as acetate, propionate, butyrate, and lactate, in addition to methane and carbon dioxide. SCFAs are a good source of energy preferred for the proliferation of colonocytes, and they help in the prevention of growing abnormal cells (by lowering intracellular $\mathrm{pH}$ ), increasing blood flow, improving the availability of some minerals such as calcium and magnesium, and the absorptions of iron $[27,44,84,89,90]$.

Many studies have reported an increase in the soluble dietary fibre (SDF) content, as a consequence of extrusion processing. The increase in SDF determined in the final extrudates was related to the presence of oligosaccharides, which resulted from the breakdown of the polysaccharides glycosidic bonds [91], the presence of new glucans branches resistant to amylase hydrolysis generated by the transglycosidation reaction between starch or fragments of starch and anhydro-compounds [92,93], the release of gums and mucilage's by the breakdown of interactions (hydrogen bonds, hydrophobic interactions or covalent bonds) between these polysaccharides and phenolic compounds [94,95], and the breaking of covalent and non-covalent linkages from the carbohydrate-protein complex $[94,96]$. The reported increase in SDF was followed by a decrease in IDF, since most of the previously mentioned reactions involve the conversion of IDF to SDF. Conversely, an increase in IDF had also been reported in other studies, as a consequence of extrusion processing. The authors justified those results by an increase in the resistant starch content, due to starch gelatinization during processing $[91,97]$, and to polysaccharide-protein complex formations (through the Maillard reaction), since these complexes present similar physico-chemical behaviour to IDF and are generally measured as lignin [91,92,94,98].

Additionally, several studies have reported that the extrusion processing conditions of moisture and temperature had a direct effect on the dietary fibre content of various food materials, as detailed in Table 3. Stojceska et al. [99] observed an increase in DF in the gluten-free products made with a variety of fruits and vegetables, Zhang et al. [100] reported that SDF in extrude oat bran had higher yields, improved rheological behaviour and functionality compared with those of SDF in unprocessed oat bran. Jing and Chi [101] made use of RSM to determine the optimum extrusion conditions for the processing of soy waste. They determined that the screw extrusion conditions of $180 \mathrm{rpm}$ increased the amount of SDF in the soy waste extrudates. Similarly, Chen et al. [102] reported an increase in SDF in soybean waste using the blast extrusion process.

Some authors have stated that the effect of the extrusion processing conditions on the content of DF depends, to a large extent, on the type of food matrix analysed [42,104]. Also, the literature indicates that there are limited studies regarding the effect of the extrusion processing conditions on the DF of pulses, compared to those reports in cereal products $[99,105,106]$ as well as in other food products $[107,108]$. Some specific studies on extruded lentil, dry pea, chickpea, and common bean, reported a partial or complete redistribution of IDF to SDF with only small changes in TDF $[3,31,42,78,81]$. Additionally, studies on the effect of extrusion processing on the DF content of some ready-to-eat products enriched with pulses, demonstrated that the improvement in the DF content in those products was dependent on the amount of pulses contained in the mixes. That is, the higher the inclusion of pulses in the mixes, the higher the content of DF, independent of the processing conditions [43,103]. 
Table 3. Extrusion processing conditions effect on the dietary fibre content (soluble, insoluble and total) content of extruded products.

\begin{tabular}{|c|c|c|c|c|c|}
\hline \multirow[t]{2}{*}{ Food Matrix } & \multirow[t]{2}{*}{ Extrusion Conditions } & \multicolumn{3}{|c|}{ Extrusion Effect (\%) } & \multirow[t]{2}{*}{ Reference } \\
\hline & & SDF & IDF & TDF & \\
\hline $\begin{array}{l}50 \% \text { rice, } 12.5 \% \text { milk powered, } \\
12.5 \% \text { potato starch, } 12.5 \% \text { corn } \\
\text { starch, } 12.5 \text { soya }\end{array}$ & $\begin{array}{l}\text { Twin; ss: } 275-350 \mathrm{rpm} ; \\
\text { bt: } 80-150{ }^{\circ} \mathrm{C} ; \mathrm{m}: 12 \% \text {; } \\
\text { ft: } 17-23 \mathrm{~kg} / \mathrm{h}\end{array}$ & & & $\uparrow 16.76-112.6$ & [99] \\
\hline $\begin{array}{l}20 \% \text { rice, } 12.5 \% \text { milk powered, } \\
12.5 \% \text { potato starch, } 12.5 \% \text { corn } \\
\text { starch, } 12.5 \text { soya, } 30 \% \text { apple }\end{array}$ & $\begin{array}{l}\text { Twin; ss: } 275-350 \mathrm{rpm} ; \\
\text { bt: } 80-150{ }^{\circ} \mathrm{C} ; \mathrm{m}: 12 \% \\
\text { ft: } 17-23 \mathrm{~kg} / \mathrm{h}\end{array}$ & & & $\uparrow 2.08-34.9$ & \\
\hline $\begin{array}{l}20 \% \text { rice, } 12.5 \% \text { milk powered, } \\
12.5 \% \text { potato starch, } 12.5 \% \text { corn } \\
\text { starch, } 12.5 \text { soya, } 30 \% \text { cranberry }\end{array}$ & $\begin{array}{l}\text { Twin; ss: } 275-350 \mathrm{rpm} ; \\
\text { bt: } 80-150{ }^{\circ} \mathrm{C} ; \mathrm{m}: 12 \% \\
\text { ft: } 17-23 \mathrm{~kg} / \mathrm{h}\end{array}$ & & & $\uparrow 7.3-33.2$ & \\
\hline $20 \%$ rice, $12.5 \%$ milk powered, & Twin; ss: 275-350 rpm; & & & $\uparrow 10.02-28.32$ & \\
\hline $\begin{array}{l}12.5 \% \text { potato starch, } 12.5 \% \text { corn } \\
\text { starch, } 12.5 \text { soya, } 30 \% \text { carrot }\end{array}$ & $\begin{array}{c}\text { bt: } 80-150^{\circ} \mathrm{C} ; \mathrm{m}: 12 \% \\
\mathrm{ft}: 17-23 \mathrm{~kg} / \mathrm{h}\end{array}$ & & & & \\
\hline $20 \%$ rice, $12.5 \%$ milk powered, & Twin; ss: 275-350 rpm; & & & $\uparrow 2.93-23.27$ & \\
\hline $\begin{array}{l}12.5 \% \text { potato starch, } 12.5 \% \text { corn } \\
\text { starch, } 12.5 \text { soya, } 30 \% \text { beetroot }\end{array}$ & $\begin{array}{c}\text { bt: } 80-150{ }^{\circ} \mathrm{C} ; \mathrm{m}: 12 \% \\
\mathrm{ft}: 17-23 \mathrm{~kg} / \mathrm{h}\end{array}$ & & & & \\
\hline $20 \%$ rice, $12.5 \%$ milk powered, & Twin; ss: 275-350 rpm; & & & $\uparrow 139.2-190.8$ & \\
\hline $\begin{array}{l}12.5 \% \text { potato starch, } 12.5 \% \text { corn } \\
\text { starch, } 12.5 \text { soya, } 30 \% \text { teff }\end{array}$ & $\begin{array}{c}\text { bt: } 80-150{ }^{\circ} \mathrm{C} ; \mathrm{m}: 12 \% \\
\mathrm{ft}: 17-23 \mathrm{~kg} / \mathrm{h}\end{array}$ & & & & \\
\hline Oat bran & $\begin{array}{c}\text { Twin; ss: } 150 \mathrm{rpm} ; \\
\text { bt: } 100-160{ }^{\circ} \mathrm{C} ; \mathrm{m}: 10-30 \% \\
\text { ft: } 18 \mathrm{~kg} / \mathrm{h}\end{array}$ & $\uparrow 11.24-59.55$ & & & [100] \\
\hline Soy waste & $\begin{array}{c}\text { Twin; ss: } 180 \mathrm{rpm} ; \mathrm{bt}: 115^{\circ} \mathrm{C} ; \\
\mathrm{m}: 31 \%\end{array}$ & $\uparrow 10.45$ & $\downarrow 10.43$ & $\uparrow 0.03$ & [101] \\
\hline Soy wasted & $\begin{array}{c}\text { Twin; ss: } 150 \mathrm{rpm} \text {; bt: } 170^{\circ} \mathrm{C} \text {; } \\
\mathrm{ft}: 30 \mathrm{~kg} / \mathrm{h}\end{array}$ & $\uparrow 27.4$ & & $\downarrow 25.7$ & [102] \\
\hline $\begin{array}{c}\text { Black bean (Phaseolus vulgaris } \\
\text { L.)3 }\end{array}$ & $\begin{array}{c}\text { Twin, ss: } 200 \mathrm{rpm} ; \mathrm{bt}: 160^{\circ} \mathrm{C} ; \\
\mathrm{m}: 20 \%\end{array}$ & $\uparrow 0.89$ & $\downarrow 1.12$ & & [81] \\
\hline $\begin{array}{l}\text { Black bean (Phaseolus vulgaris L.) } \\
+0.2 \% \mathrm{NaHCO}_{3}\end{array}$ & $\begin{array}{c}\text { Twin, ss: } 200 \text { rpm; bt: } 160^{\circ} \mathrm{C} ; \\
\text { m: } 20 \%\end{array}$ & $\uparrow 2.91$ & $\downarrow 3.54$ & & \\
\hline Lentil (Lens culinaris L.) & $\begin{array}{c}\text { Twin; ss: } 500 \text { rpm; bt: } 160^{\circ} \mathrm{C} \text {; } \\
\mathrm{m:} 17 \%\end{array}$ & $\uparrow 0.44$ & $\downarrow 4.66$ & $\downarrow 4.22$ & [78] \\
\hline $\begin{array}{l}\text { Lentil (Lens culinaris L.) + wheat } \\
\text { bran + apple fibre }\end{array}$ & $\begin{array}{c}\text { Twin; ss: } 500 \text { rpm; bt: } 160^{\circ} \mathrm{C} ; \\
\mathrm{m}: 17 \%\end{array}$ & $\uparrow 0.63$ & $\downarrow 0.56$ & $\uparrow 0.07$ & \\
\hline $\begin{array}{l}\text { Lentil (Lens culinaris L.) + wheat } \\
\text { bran + NUTRIOSE }\end{array}$ & $\begin{array}{c}\text { Twin; ss: } 500 \text { rpm; bt: } 160{ }^{\circ} \mathrm{C} \text {; } \\
\text { m: } 17 \%\end{array}$ & $\uparrow 0.04$ & $\downarrow 4.03$ & $\downarrow 3.9$ & \\
\hline $\begin{array}{l}\text { Lentil (Lens culinaris L.) }+ \text { apple } \\
\text { fibre + NUTRIOSE }\end{array}$ & $\begin{array}{c}\text { Twin; ss: } 500 \text { rpm; bt: } 160^{\circ} \mathrm{C} \text {; } \\
\text { m: } 17 \%\end{array}$ & $\uparrow 0.02$ & $\downarrow 1.2$ & $\downarrow 2.38$ & \\
\hline $\begin{array}{l}\text { Lentil (Lens culinaris L.) + apple } \\
\text { fibre + corn fibre }\end{array}$ & $\begin{array}{c}\text { Twin; ss: } 500 \text { rpm; bt: } 160^{\circ} \mathrm{C} \text {; } \\
\mathrm{m:} 17 \%\end{array}$ & $\uparrow 0.11$ & $\downarrow 0,84$ & $\uparrow 0.08$ & \\
\hline Lentil (Lens culinaris L.) & $\begin{array}{c}\text { Twin; ss: } 500 \text { rpm; bt: } 140^{\circ} \mathrm{C} \text {; } \\
\text { m: } 17 \%\end{array}$ & $\uparrow 1.59$ & $\uparrow 4.92$ & $\uparrow 6.5$ & [42] \\
\hline Lentil (Lens culinaris L.) & $\begin{array}{c}\text { Twin; ss: } 500 \text { rpm; bt: } 160^{\circ} \mathrm{C} \text {; } \\
\text { m: } 17 \%\end{array}$ & $\uparrow 0.35$ & $\uparrow 3.23$ & $\uparrow 3.57$ & \\
\hline $\begin{array}{l}\text { Broken rice }+ \text { bean grains } \\
\text { ("Carioca" type) }\end{array}$ & $\begin{array}{c}\text { Twin; ss: } 277 \text { rpm; bt: } 80^{\circ} \mathrm{C} \text {; } \\
\text { m: } 14 \%\end{array}$ & & & $\downarrow 14.4$ & [103] \\
\hline $\begin{array}{c}80 \% \text { rice }+20 \% \text { bean (Phaseolus } \\
\text { vulgaris L.) }\end{array}$ & $\begin{array}{l}\text { Twin; ss: } 900-950 \mathrm{rpm} ; \\
\text { bt: } 125^{\circ} \mathrm{C} ; \mathrm{m}: 10-12 \%\end{array}$ & $\uparrow 2.39$ & $\downarrow 5.53$ & $\downarrow 3.16$ & [43] \\
\hline $\begin{array}{c}60 \% \text { rice }+40 \% \text { bean (Phaseolus } \\
\text { vulgaris L.) }\end{array}$ & $\begin{array}{l}\text { Twin; ss: } 900-950 \mathrm{rpm} ; \\
\text { bt: } 125^{\circ} \mathrm{C} ; \mathrm{m}: 10-12 \%\end{array}$ & $\downarrow 3.34$ & $\downarrow 5.89$ & $\uparrow 2.56$ & \\
\hline
\end{tabular}

SDF: soluble dietary fibre; IDF: insoluble dietary fibre; TDF: total dietary fibre; twin: type of screw; ss: screw speed; bt: barrel temperature; $\mathrm{ft}$ : feed temperature; m: moisture; $\uparrow:$ increase; $\downarrow$ : decrease. 


\subsection{2. $\alpha$-Galactosides and the Impact of Extrusion Process on Oligosaccharides}

The $\alpha$-galactosidic bonds in the oligosaccharides (raffinose, stachyose, verbascose and ciceritol) present in pulses cannot be metabolized by the human intestinal tract due to the lack of an $\alpha$-galactosidase enzyme. Therefore, these carbohydrates remain undigested in the human intestine, where they are fermented by intestinal bacteria generating flatulence $[109,110]$. Despite the indicated undesirable effect caused by the indigestible oligosaccharides, it has been reported that the oligosaccharides can increase the bifidobacteria population in the colon, and in turn they act on stimulating the immune system and reducing digestive disorders $[28,111]$. Extrusion was reported to decrease the oligosaccharides content in the extrudates from different whole pulse flours, processed under high temperatures and frictional forces, which break down the oligosaccharides into more digestible carbohydrate components [12,77,112]. A similar effect to oligosaccharides has also been reported in the extruded samples of rice enriched with bean or pea flours, as detailed in Table $4[43,82]$.

Table 4. Effect of processing conditions on oligosaccharides content in pulse extrudates.

\begin{tabular}{|c|c|c|c|c|c|c|c|c|}
\hline \multirow[t]{2}{*}{ Food Matrix } & \multirow[t]{2}{*}{ Extrusion Conditions } & \multicolumn{6}{|c|}{ Oligosaccharides $(\mathrm{mg} / \mathrm{g})$} & \multirow[t]{2}{*}{ Reference } \\
\hline & & Galactinol & Ciceritol & Galactopinitol & Verbascose & Raffinose & Stachyose & \\
\hline Pea & Non-Extruded & & & & 14.0 & 9.2 & 23.0 & \multirow{4}{*}{ [77] } \\
\hline (Pisum sativum L.) & $\begin{array}{l}\text { Twin; ss: } 100 \mathrm{rpm} ; \\
\text { bt: } 150^{\circ} \mathrm{C} ; \mathrm{m}: 25 \%\end{array}$ & & & & 18.7 & 9.7 & 18.5 & \\
\hline \multirow{2}{*}{$\begin{array}{c}\text { Kidney bean } \\
\text { (Phaseolus vulgaris L.) }\end{array}$} & Non-Extruded & & & & 2.4 & 6.4 & 41.4 & \\
\hline & $\begin{array}{l}\text { Twin; ss: } 100 \text { rpm; } \\
\text { bt: } 150^{\circ} \mathrm{C} ; \mathrm{m}: 25 \%\end{array}$ & & & & 1.9 & 2.2 & 33.6 & \\
\hline Dry pea & Non-Extruded & - & n.d. & - & - & 15.64 & 20.19 & \multirow{6}{*}{ [3] } \\
\hline (Pisum sativum L.) & $\begin{array}{l}\text { Twin; ss: } 500 \text { rpm; } \\
\text { bt: } 160^{\circ} \mathrm{C} ; \mathrm{m}: 17 \%\end{array}$ & - & n.d. & - & - & 8.16 & 15.29 & \\
\hline Chickpea & Non-Extruded & - & 2.686 & - & - & 6.05 & 14.14 & \\
\hline (Cicer arietinum L.) & $\begin{array}{l}\text { Twin; ss: } 500 \text { rpm; } \\
\text { bt: } 160^{\circ} \mathrm{C} ; \mathrm{m}: 17 \%\end{array}$ & - & 2.880 & - & - & 7.54 & 18.85 & \\
\hline \multirow{2}{*}{$\begin{array}{c}\text { Lentil } \\
\text { (Lens culinaris L.) }\end{array}$} & Non-Extruded & - & 2.249 & - & - & 12.08 & n.e. & \\
\hline & $\begin{array}{l}\text { Twin; ss: } 500 \text { rpm; } \\
\text { bt: } 160{ }^{\circ} \mathrm{C} ; \mathrm{m}: 17 \%\end{array}$ & - & 2.372 & - & - & 2.22 & 11.80 & \\
\hline \multirow{4}{*}{$\begin{array}{c}\text { Pea } \\
\text { (Pisum sativum var. } \\
\text { laguna seeds) }\end{array}$} & Non-Extruded & - & - & - & $6.0 \pm 0.03$ & $\begin{array}{c}11.4 \pm \\
0.04\end{array}$ & $\begin{array}{c}23.6 \pm \\
0.07\end{array}$ & \multirow{4}{*}{ [112] } \\
\hline & $\begin{array}{c}\text { Single; ss: } 60 \mathrm{rpm} ; \\
\text { bt: } 129^{\circ} \mathrm{C} ; \mathrm{m}: 40 \mathrm{~L} / \mathrm{h}\end{array}$ & - & - & - & $5.3 \pm 0.02$ & & $\begin{array}{c}20.4 \pm \\
0.05\end{array}$ & \\
\hline & $\begin{array}{l}\text { Single; ss: } 60 \mathrm{rpm} ; \\
\text { bt: } 135^{\circ} \mathrm{C} ; \mathrm{m}: 35 \mathrm{~L} / \mathrm{h}\end{array}$ & - & - & - & $4.8 \pm 0.03$ & $7.4 \pm 0.04$ & $\begin{array}{c}17.5 \pm \\
0.06\end{array}$ & \\
\hline & $\begin{array}{l}\text { Single; ss: } 60 \mathrm{rpm} ; \\
\text { bt: } 142^{\circ} \mathrm{C} ; \mathrm{m}: 25 \mathrm{~L} / \mathrm{h}\end{array}$ & - & - & - & $4.7 \pm 0.02$ & $7.6 \pm 0.04$ & $\begin{array}{c}17.3 \pm \\
0.03\end{array}$ & \\
\hline \multirow{2}{*}{$\begin{array}{l}\text { Lentil } \\
\text { (Lens culinaris L. } \\
\text { Medik) }\end{array}$} & Non-Extruded & $0.32 \pm 0.01$ & $23.05 \pm 0.59$ & $1.82 \pm 0.05$ & $16.54 \pm 0.41$ & $\begin{array}{c}2.72 \pm \\
0.20\end{array}$ & $\begin{array}{c}22.42 \pm \\
1.74\end{array}$ & \multirow[b]{2}{*}{ [12] } \\
\hline & $\begin{array}{l}\text { Twin; ss: } 500 \text { rpm; } \\
\text { bt: } 160^{\circ} \mathrm{C} ; \mathrm{m}: 17 \%\end{array}$ & $1.36 \pm 0.16$ & $26.65 \pm 0.77$ & $2.84 \pm 0.18$ & $13.64 \pm 0.46$ & $\begin{array}{l}4.22 \pm \\
0.26\end{array}$ & $\begin{array}{c}24.67 \pm \\
0.76\end{array}$ & \\
\hline Rice $(80 \%)+$ Pea & Non-Extruded & 0.27 & n.d. & - & 7.44 & 3.06 & 4.85 & \multirow[b]{2}{*}{ [82] } \\
\hline $\begin{array}{c}\text { (Pisum sativum L.) } \\
(20 \%)\end{array}$ & $\begin{array}{c}\text { Twin; ss: } 900 \mathrm{rpm} ; \\
\text { bt: } 125^{\circ} \mathrm{C} ; \mathrm{m}: 2.50 \mathrm{~kg} / \mathrm{h}\end{array}$ & 17.87 & 0.34 & - & 10.97 & 6.36 & 7.47 & \\
\hline \multirow{2}{*}{$\begin{array}{c}\text { Rice }(60 \%)+\text { Pea } \\
\text { (Pisum sativum L.) } \\
(40 \%)\end{array}$} & Non-Extruded & 0.37 & 0.59 & - & 14.0 & 3.99 & 8.83 & \\
\hline & $\begin{array}{c}\text { Twin; ss: } 950 \mathrm{rpm} ; \\
\text { bt: } 125^{\circ} \mathrm{C} ; \mathrm{m}: 2.50 \mathrm{~kg} / \mathrm{h}\end{array}$ & 8.84 & 1.05 & - & 22.01 & 8.51 & 11.89 & \\
\hline \multirow{2}{*}{$\begin{array}{c}\text { Rice }(80 \%)+\text { Bean } \\
\text { (Phaseolus vulgaris L.) } \\
(20 \%)\end{array}$} & Non-Extruded & $2.53 \pm 0.10$ & $0.78 \pm 0.04$ & - & & $\begin{array}{c}2.84 \pm \\
0.13\end{array}$ & $\begin{array}{c}8.55 \pm \\
0.40\end{array}$ & \multirow{4}{*}{ [43] } \\
\hline & $\begin{array}{c}\text { Twin; ss: } 900 \mathrm{rpm} ; \\
\text { bt: } 125^{\circ} \mathrm{C} ; \mathrm{m}: 2.50 \mathrm{~kg} / \mathrm{h}\end{array}$ & $2.84 \pm 0.11$ & $5.44 \pm 0.07$ & - & & $\begin{array}{c}9.46 \pm \\
0.35\end{array}$ & $\begin{array}{c}10.30 \pm \\
0.43\end{array}$ & \\
\hline \multirow{2}{*}{$\begin{array}{c}\text { Rice }(60 \%)+\text { Bean } \\
\text { (Phaseolus vulgaris L.) } \\
(40 \%)\end{array}$} & Non-Extruded & $3.58 \pm 0.03$ & $1.14 \pm 0.05$ & - & & $\begin{array}{c}3.87 \pm \\
0.04\end{array}$ & $\begin{array}{c}11.82 \pm \\
0.23\end{array}$ & \\
\hline & $\begin{array}{c}\text { Twin; ss: } 950 \mathrm{rpm} ; \\
\text { bt: } 125^{\circ} \mathrm{C} ; \mathrm{m}: 2.50 \mathrm{~kg} / \mathrm{h}\end{array}$ & $3.81 \pm 0.10$ & $8.92 \pm 0.07$ & - & & $\begin{array}{c}12.21 \pm \\
0.24\end{array}$ & $\begin{array}{c}20.91 \pm \\
0.13\end{array}$ & \\
\hline
\end{tabular}

Twin or single: type of screw; ss: screw speed; bt: barrel temperature; ft: feed temperature; m: moisture; n.e.: not evaluated.

The observed decrease in the oligosaccharides content resulted in an increase in their carbohydrate components. Some authors have indicated that the increase in the carbohydrates components could be due to the modification of the food matrix structure, such as the release of oligosaccharides linked to other macromolecules, cell wall breakage, and the improvement in the porosity and specific surface area, which facilitates the extraction of 
the component soluble sugars. A particular study reported that the decrease in oligosaccharides in extruded black bean flour may be due to the breakdown of the $(2 \rightarrow 1)$ furanosidic bond, due to the high temperatures used in the extrusion process [81]. Verbascose is a penta-oligosaccharide conformed by the linkage of stachyose and raffinose, consequently the hydrolysis of verbascose generates the release (increase) of its component sugars [12,80].

\subsection{Vitamins Content in Extruded Pulses Products}

Vitamins are organic elements present in most natural foods that are essential for physiological functions, but when these are thermally/cook processed, particularly by the extrusion process, a relevant amount of the vitamins are lost [113].

As vitamins differ greatly in their structure and chemical composition, their stability during extrusion is also variable [7]. The extent of the vitamins degradation depends on their exposure to certain parameters encountered during food processing and storage, such as moisture, temperature, light, oxygen, time, and $\mathrm{pH}$ [57].

Water-soluble vitamins are more liable to be destroyed by their exposure to high temperatures encountered during the extrusion process, than fat-soluble vitamins. The fat-soluble vitamins most sensitive to extrusion cooking are vitamin $\mathrm{A}$ and vitamin $\mathrm{E}$, while vitamins D and $\mathrm{K}$ are quite stable $[7,113]$. Provitamin A (carotenoids) and tocopherols (with vitamin $\mathrm{E}$ activity) are not stable in the presence of oxygen and heat. The main factor contributing to the reduction in $\beta$-carotene during extrusion is thermal degradation [57].

Table 5 shows some examples of the effect of extrusion processing conditions on the vitamin content of several pulses. Morales et al. [78] observed that extrusion caused a significant decrease (83-94\%) in the tocopherols content in extrudates formulated with red chief lentils (Lens culinaris L.). Similarly, Ciudad-Mulero et al. [42] reported a reduction of $81.5-92 \%$ in the tocopherols content of extruded lentils. Zieliński et al., [114] determined a significant decrease (63-94\%) in the tocopherols and tocotrienols content in extruded cereals. In addition, they observed that the proportion of tocotrienols to tocopherols increased after extrusion cooking, indicating that tocotrienols were the main residual isomers of vitamin E.

As previously indicated that the water-soluble vitamins present at a lower heat stability than the fat-soluble vitamins. Riaz et al. [113] reported that the most sensitive water-soluble vitamins during heat processing were vitamin $C$, thiamine $\left(B_{1}\right)$ and folic acid $\left(\mathrm{B}_{9}\right)$. Camire et al., [116] corroborated that thiamine and pyridoxine were the most thermolabile of the water-soluble vitamins and that their levels decreased linearly with increased processing temperatures. Brennan et al., [117] reported that high extrusion temperatures and low feed moisture promoted great degradation of ascorbic acid. Similar processing conditions were reported by Gulati and Rose [118] to also degrade folic acid. Conversely, water-soluble vitamins, such as $B_{2}, B_{6}, B_{12}$, niacin, pantothenic acid, and biotin, were determined to be largely stable during the high-temperature conditions of the extrusion process [57].

Moreover, Athar et al., [115] concluded that some water-soluble vitamins were not highly affected by extrusion temperature and other extrusion conditions, when processed using a short-barrel extruder with a low retention time. Since, after processing a mixture of corn and pea, the extruded product presented a $61,60,70$ and $18 \%$ retention of thiamine, niacin, riboflavin, and pyridoxine, respectively. Thus, an effective way to minimize the loss of vitamins in extruded food materials is to process them under mild extrusion temperatures and a short retention time.

Furthermore, Singh et al., [57] proposed nutritional enrichment options in order to maintain good levels of vitamins in the final processed and stored products. The proposed nutritional enrichment options included specific vitamin compounds and/or specific chemical forms with better stability, as well as enrichment with extra value amounts of nutrients. Also, the post-extrusion addition of vitamins. 
Table 5. Effect of extrusion processing conditions on the vitamins content of pulse and cereal extrudates.

\begin{tabular}{|c|c|c|c|c|c|}
\hline \multirow[t]{2}{*}{ Vitamin } & \multirow[t]{2}{*}{ Food Matrix } & \multirow[t]{2}{*}{ Extrusion Conditions } & \multicolumn{2}{|c|}{ Effect (mg/100 g) } & \multirow[t]{2}{*}{ Reference } \\
\hline & & & No-Extruded & Extruded & \\
\hline \multirow{14}{*}{ Tocopherols } & \multirow{3}{*}{ (Wheat cv. Almari) } & Twin, ss: $500 \mathrm{rpm}, \mathrm{bt}: 120^{\circ} \mathrm{C}, \mathrm{m}: 20 \%$ & \multirow[t]{3}{*}{2.78} & 0.862 & \multirow{11}{*}{ [114] } \\
\hline & & Twin, ss: $500 \mathrm{rpm}, \mathrm{bt}: 160^{\circ} \mathrm{C}, \mathrm{m}: 20 \%$ & & 0.623 & \\
\hline & & Twin, ss: 500 rpm, bt: $200^{\circ} \mathrm{C}, \mathrm{m}: 20 \%$ & & 0.933 & \\
\hline & \multirow{3}{*}{ (Barley cv. Gregor) } & Twin, ss: $500 \mathrm{rpm}, \mathrm{bt:} 120^{\circ} \mathrm{C}, \mathrm{m}: 20 \%$ & \multirow[t]{3}{*}{1.873} & 0.354 & \\
\hline & & Twin, ss: $500 \mathrm{rpm}, \mathrm{bt}: 160^{\circ} \mathrm{C}, \mathrm{m}: 20 \%$ & & 0.382 & \\
\hline & & Twin, ss: 500 rpm, bt: $200^{\circ} \mathrm{C}, \mathrm{m}: 20 \%$ & & 0.31 & \\
\hline & \multirow{3}{*}{$\begin{array}{c}\text { Rye (cv. } \\
\text { Dankowskie Złote) }\end{array}$} & Twin, ss: $500 \mathrm{rpm}, \mathrm{bt}: 120^{\circ} \mathrm{C}, \mathrm{m}: 20 \%$ & \multirow[t]{3}{*}{2.778} & 0.608 & \\
\hline & & Twin, ss: $500 \mathrm{rpm}, \mathrm{bt}: 160^{\circ} \mathrm{C}, \mathrm{m}: 20 \%$ & & 0.885 & \\
\hline & & Twin, ss: 500 rpm, bt: $200^{\circ} \mathrm{C}, \mathrm{m}: 20 \%$ & & 0.872 & \\
\hline & \multirow{2}{*}{ Oat (cv. Sławko) } & Twin, ss: 500 rpm, bt: $120^{\circ} \mathrm{C}, \mathrm{m}: 20 \%$ & \multirow[t]{2}{*}{1.159} & 0.732 & \\
\hline & & Twin, ss: 500 rpm, bt: $200^{\circ} \mathrm{C}, \mathrm{m}: 20 \%$ & & 0.099 & \\
\hline & \multirow{3}{*}{$\begin{array}{l}\text { Lentil (Lens } \\
\text { culinaris L.) }\end{array}$} & Twin, ss: $500 \mathrm{rpm}, \mathrm{bt}: 160^{\circ} \mathrm{C}, \mathrm{m}: 17 \%$ & \multirow{3}{*}{$\begin{array}{l}6.17 \pm 0.25 \\
2.55 \pm 0.01\end{array}$} & $1.02 \pm 0.17$ & \multirow{3}{*}{$\begin{array}{l}{[78]} \\
{[42]}\end{array}$} \\
\hline & & Twin; ss: 500 rpm; bt: $140{ }^{\circ} \mathrm{C} ; \mathrm{m}: 17 \%$ & & $0.30 \pm 0.01$ & \\
\hline & & Twin; ss: 500 rpm; bt: $160{ }^{\circ} \mathrm{C}$; m: $17 \%$ & & n.d. & \\
\hline \multirow[t]{8}{*}{ Thiamine } & Oats & Single; ss: $0.012 \mathrm{kWhkg}^{-1}$, bt: $152{ }^{\circ} \mathrm{C}, \mathrm{m}: 7 \%$ & 0.11 & $23 *$ & \multirow{5}{*}{ [115] } \\
\hline & Maize & Single; ss: $0.095 \mathrm{kWhkg}^{-1}$, bt: $130{ }^{\circ} \mathrm{C}, \mathrm{m:}: 7 \%$ & 0.09 & $62 *$ & \\
\hline & & Single; ss: $0.095 \mathrm{kWhkg}^{-1}, \mathrm{bt}: 152{ }^{\circ} \mathrm{C}, \mathrm{m}: 7 \%$ & & $44^{*}$ & \\
\hline & & Single; ss: $0.095 \mathrm{kWhkg}^{-1}, \mathrm{bt}: 160^{\circ} \mathrm{C}, \mathrm{m}: 7 \%$ & & $62 *$ & \\
\hline & $\begin{array}{l}\text { Maize + dried } \\
\text { green peas }\end{array}$ & Single; ss: $0.095 \mathrm{kWhkg}^{-1}$, bt: $152{ }^{\circ} \mathrm{C}, \mathrm{m}: 7 \%$ & 0.22 & $61 *$ & \\
\hline & \multirow{3}{*}{$\begin{array}{l}\text { Pea (Pisum sativum } \\
\text { L. var. laguna) }\end{array}$} & Single; ss: $60 \mathrm{rpm}, \mathrm{bt}: 129^{\circ} \mathrm{C}, \mathrm{m}: 40 \mathrm{~L} / \mathrm{h}$ & $0.196 \pm 0.012$ & $0.104 \pm 0.009$ & \multirow{3}{*}{ [112] } \\
\hline & & Single; ss: $60 \mathrm{rpm}, \mathrm{bt:} 135^{\circ} \mathrm{C}, \mathrm{m}: 35 \mathrm{~L} / \mathrm{h}$ & & $0.100 \pm 0.008$ & \\
\hline & & Single; ss: $60 \mathrm{rpm}, \mathrm{bt}: 142{ }^{\circ} \mathrm{C}, \mathrm{m}: 25 \mathrm{~L} / \mathrm{h}$ & & $0.089 \pm 0.005$ & \\
\hline \multirow[t]{8}{*}{ Riboflavin } & Oats & Single; ss: $0.012 \mathrm{kWhkg}^{-1}$, bt: $152{ }^{\circ} \mathrm{C}, \mathrm{m}: 7 \%$ & 0.06 & $100 *$ & \multirow{5}{*}[115]{} \\
\hline & Maize & Single; ss: $0.095 \mathrm{kWhkg}^{-1}$, bt: $130{ }^{\circ} \mathrm{C}, \mathrm{m}: 7 \%$ & 0.04 & $100 *$ & \\
\hline & & Single; ss: $0.095 \mathrm{kWhkg}^{-1}$, bt: $152{ }^{\circ} \mathrm{C}, \mathrm{m}: 7 \%$ & & $86^{*}$ & \\
\hline & & Single; ss: $0.095 \mathrm{kWhkg}^{-1}$, bt: $160^{\circ} \mathrm{C}, \mathrm{m}: 7 \%$ & & $100 *$ & \\
\hline & Maize + dried & Single; ss: $0.095 \mathrm{kWhkg}^{-1}$, bt: $152^{\circ} \mathrm{C}, \mathrm{m}: 7 \%$ & 0.08 & $70 *$ & \\
\hline & \multirow{3}{*}{$\begin{array}{l}\text { Pea (Pisum sativum } \\
\text { L. var. laguna) }\end{array}$} & & $0102+0004$ & & \\
\hline & & $\begin{array}{l}\text { Single; ss: } 60 \mathrm{rpm} \text {, bt: } 129^{\circ} \mathrm{C}, \mathrm{m}: 40 \mathrm{~L} / \mathrm{h} \\
\text { Single; ss: } 60 \mathrm{rpm} \text { bt: } 135^{\circ} \mathrm{C}, \mathrm{m}: 35 \mathrm{~L} / \mathrm{h}\end{array}$ & & $\begin{array}{l}0.096 \pm 0.006 \\
0.087+0.005\end{array}$ & [112] \\
\hline & & Single; ss: $60 \mathrm{rpm}, \mathrm{bt}: 142^{\circ} \mathrm{C}, \mathrm{m}: 25 \mathrm{~L} / \mathrm{h}$ & & $0.089 \pm 0.004$ & \\
\hline Niacin & Oats & Single; ss: $0.012 \mathrm{kWhkg}^{-1}$, bt: $152^{\circ} \mathrm{C}, \mathrm{m}: 7 \%$ & 1.35 & $100 *$ & \\
\hline & Maize & Single; ss: $0.095 \mathrm{kWhkg}^{-1}$, bt: $130{ }^{\circ} \mathrm{C}, \mathrm{m}: 7 \%$ & 0.63 & $83 *$ & \\
\hline & & Single; ss: $0.095 \mathrm{kWhkg}^{-1}$, bt: $152{ }^{\circ} \mathrm{C}, \mathrm{m}: 7 \%$ & & $75^{*}$ & [115] \\
\hline & & Single; ss: $0.095 \mathrm{kWhkg}^{-1}$, bt: $160{ }^{\circ} \mathrm{C}, \mathrm{m}: 7 \%$ & & $73 *$ & {$[110]$} \\
\hline & $\begin{array}{l}\text { Maize + dried } \\
\text { green peas }\end{array}$ & Single; ss: $0.095 \mathrm{kWhkg}^{-1}$, bt: $152{ }^{\circ} \mathrm{C}, \mathrm{m}: 7 \%$ & 1.85 & $60 *$ & \\
\hline Pyridoxine & Oats & Single; ss: $0.012 \mathrm{kWhkg}^{-1}$, bt: $152{ }^{\circ} \mathrm{C}, \mathrm{m}: 7 \%$ & 0.10 & $35 *$ & \\
\hline & Maize & Single; ss: $0.095 \mathrm{kWhkg}^{-1}$, bt: $130{ }^{\circ} \mathrm{C}, \mathrm{m}: 7 \%$ & 0.04 & $86^{*}$ & \\
\hline & & Single; ss: $0.095 \mathrm{kWhkg}^{-1}$, bt: $152^{\circ} \mathrm{C}, \mathrm{m}: 7 \%$ & & $100 *$ & \\
\hline & & Single; ss: $0.095 \mathrm{kWhkg}^{-1}$, bt: $160{ }^{\circ} \mathrm{C}, \mathrm{m}: 7 \%$ & & $100 *$ & [115] \\
\hline & $\begin{array}{c}\text { Maize + dried } \\
\text { green peas (Pisum } \\
\text { sativum L.) }\end{array}$ & Single; ss: $0.095 \mathrm{kWhkg}^{-1}$, bt: $152{ }^{\circ} \mathrm{C}, \mathrm{m}: 7 \%$ & 0.06 & $18^{*}$ & \\
\hline
\end{tabular}

Twin or single: type of screw; ss: screw speed; bt: barrel temperature; m: moisture; n.d.: not detected; ${ }^{*}$ values expressed in percentage of retention. 


\subsection{Phenolic Compounds in Extruded Pulse Products}

Phenolic compounds are bioactive secondary plant metabolites synthesized during the normal development of the plant, or generated as a response to stress conditions in order to protect the plant against predators, pathogens, parasites or UV radiation. Phenolic compounds have an antioxidant capacity that neutralizes free radicals to prevent damage due to oxidative stress. Therefore, phenolics are effective anti-inflammatory compounds and have antimicrobial properties, both of which are associated with health benefits. A large number of authors have agreed that phenolic compounds could help in the prevention of cardiovascular diseases, inflammation and diabetes [119-123].

The phenolic compounds present in major quantities in pulses are flavonoids, tannins, and phenolic acids. Among them, phenolic acids are the most representative of the phenolic compounds. There are the following two classes of phenolic acids: hydroxybenzoic acids and hydroxycinnamic acids (chiefly coumaric, caffeic and ferulic acids) [124]. In 2007, $\mathrm{Xu}$ and Chang [125] determined the presence of phenolic compounds in different pulses, and they reported that lentils presented good values of gallic acid (6.56 $\mathrm{mg} \mathrm{GAE} \mathrm{g}^{-1}$ for phenolic compounds) and catechin (1.30 $\mathrm{mg} \mathrm{CE} \mathrm{g}^{-1}$ for flavonoids and $5.97 \mathrm{mg} \mathrm{CE} \mathrm{g}^{-1}$ for condensed tannin). They also indicated that lentil was the pulse with the highest amounts and better antioxidant activity, followed by red kidney and black beans. Additionally, they concluded that the content of phenolic compounds in pulses depended on genetic, environmental factors, and the type of pulse.

Even though phenolic compounds are excellent antioxidant agents, heat causes the degradation of phenolics, mainly by decarboxylation. Some authors have reported that the high-temperature conditions used in extrusion cooking promoted a decrease in the content and stability of the phenolic compounds [126]. In addition to temperature (the most influential parameter), some studies demonstrated that a low moisture content in the feed also has a detrimental effect on the phenolics content of the extruded products [127]. Furthermore, high-temperature extrusion conditions can lead to polymerization of some phenolic compounds [128,129].

However, despite the reported decrease in the phenolic compounds induced by extrusion cooking, the percentage decrease in antioxidant activity determined in the final extrudates was variable [128,130]. Extrusion may disrupt/break covalent bonds in a high molecular weight polyphenolic complex, generating other phenolic compounds, as well as releasing combined phenolics bound to dietary fibre and/or proteins $[129,131]$.

Brennan et al. [117] and Nayak et al. [132] reported that the effect of extrusion in phenolic compounds was affected by many variables, such us the type of phenolic compound, the extrusion processing conditions, and/or the characteristics of the food matrix. Sensoy et al. [133] reported that the extrusion of buckwheat (Fagopyrum esculantum Moench) flour, processed at a temperature of $170{ }^{\circ} \mathrm{C}$, did not generate any change in the antioxidant activity of phenolics, while roasting at $200{ }^{\circ} \mathrm{C}$ for ten minutes promoted a decrease in the antioxidant activity of the processed product. They concluded that the functionality of active compounds could be maintained by the optimization of time and processing temperature. Moreover, Korus et al. [134] demonstrated that the type of cultivar highly affected the phenolic content determined in the processed products. They reported that the total phenolic content in a common bean (Phaseolus vulgaris L.) variety, rawela (dark red) was $14 \%$ higher than in other two bean varieties, tip-top (black-brown) and toffi (Cream), after processing them under the same conditions.

Ciudad-Mulero et al. [42] analysed the phenolic content of different extruded lentil flours formulated with nutritional yeast, processed at a die temperature of $140{ }^{\circ} \mathrm{C}$ and $160{ }^{\circ} \mathrm{C}$, with a moisture feed of $17 \%$ and screw speed of $500 \mathrm{rpm}$. They reported a decrease in the total phenolic content in all samples, but especially in those samples extruded at the higher temperature of $160{ }^{\circ} \mathrm{C}$ and the higher inclusion of nutritional yeast (12 and $16 \%$ ) in the formulations. Conversely, the antioxidant activity determined in most of the extruded sample flours increased significantly. 


\subsection{Antinutritional Compounds in Extruded Pulse Products}

The nutritional value of pulses may be negatively affected by the presence of antiphysiological substances that can disrupt the process of assimilation in some nutrients, reduce the nutritive value of pulse-based foods, and can even be toxic. Those substances are generally called antinutritional compounds (ANCs) and have been categorized into two groups. The first group is represented by protein ANCs, which includes antimicrobial proteins such as lectins or agglutinins, and protease enzyme inhibitors like trypsin and chymotrypsin inhibitors. The second group is represented by non-protein ANCs, which includes saponins and other glycosides, alkaloids, phytic acid or phenolic compounds such as tannins [135-140]. Other studies, however, have demonstrated that the use of ANCs in specific amounts can help in the prevention of different diseases like cancer and coronary diseases [141-143].

Inositol hexaphosphate (IP6) or phytic acid present in pulses, are considered as antinutritional compounds for their capacity to effect complex minerals, such as zinc and calcium, which hinder their absorption. Nevertheless, less phosphorylated forms of inositol phosphate (IP5 and IP4) have demonstrated to have beneficial antioxidant activity [12,43]. Moreover, less phosphorylated forms of inositol phosphate have shown to have a negligible complex capacity for impairing mineral absorption [144]. The main extrusion processing conditions of temperature, moisture and screw speed have demonstrated to promote the partial hydrolysis of IP6 into less phosphorylated forms, rendering extruded products with the subsequent potential beneficial effect of the less phosphorylated forms IP4 and IP5. In this regard, Alonso et al. [77] reported the findings of a study using pea and kidney bean flours, processed in a twin-screw extruder at a screw speed of $100 \mathrm{rpm}, 25 \%$ feed moisture, and die temperatures of $150{ }^{\circ} \mathrm{C}$ and $155^{\circ} \mathrm{C}$. The contents of inositol phosphate, in both of the extruded flours, were determined using high-performance liquid chromatographic (HPLC). The analytical results showed a decrease in the IP6 content of $27.67 \%$ and $26.81 \%$ for extruded pea and kidney bean flour, respectively, and a significant increase in the IP5 and IP4 content.

El-Hady and Habiba [61] reported that other extrusion processing conditions can also influence the amounts of IP in the final extrudates. They extruded faba bean, pea, chickpea and kidney bean flours at two barrel temperatures $\left(140{ }^{\circ} \mathrm{C}\right.$ and $\left.180^{\circ} \mathrm{C}\right)$ and two feed moisture contents (18\% and $22 \%$ ). They determined, in all of the extruded flours, a reduction in phytic acid (IP6), especially in the samples processed at a temperature of $180^{\circ} \mathrm{C}$ and 22\% moisture content. A similar finding was reported by Rathod and Annapure [66], who processed a mixture of $40 \%$ lentil and $60 \%$ rice flour under the extrusion conditions of 70,95 and $120^{\circ} \mathrm{C}$ barrel temperature and 16, 20 and $24 \%$ feed moisture content. They evidenced the highest reduction in phytic acid (IP6) at the processing conditions of $120^{\circ} \mathrm{C}$ and $24 \%$ moisture. Batista et al. [63] quantified the amount of phytic acid present in the raw and extruded flours of two hard-to-cook beans of different cultivars. The beans were extruded at a die temperature of $150{ }^{\circ} \mathrm{C}$, screw speed of $150 \mathrm{rpm}$ and feed moisture of $20 \%$. The raw flours of the two bean cultivars (Pontal and Grafite) had phytic acid contents of 8.18 and $11.26 \mathrm{mg} / \mathrm{g}(\mathrm{dwb})$, respectively, which indicated the influence of cultivar in their composition. After the extrusion process, the phytic acid content in the flour of Pontal and Grafite showed a reduction of $17 \%$ and $26 \%$, respectively.

Also, the composition of the initial food mix influences the content of IP in the final extrudate. Morales et al. [12] reported that lentil flour enriched with wheat bran, NUTRIOSE ${ }^{\circledR}$ or apple fibre presented a higher reduction in IP6 than lentil flour enriched with corn fibre, even though the determined decrease was not significant. Similarly, Arribas et al. [43] extruded a mix of bean flour (20-40\%) with different percentages of rice $(50-80 \%)$ and carob fruit $(5-10 \%)$. The authors reported that the extrusion process significantly reduced the phytic acid content $(10 \%)$ and significantly increased the content of less phosphorylated forms (16-70\%). More specifically, there was a significant increase in the IP4 (16-52\%) and IP5 (30-70\%) forms of phytic acid. They also concluded that the reduction in phytic acid (IP6) content was higher in samples without carob fruit and less in the formulations containing a higher amount of pulses in the mixes. 
Regarding tannins, these compounds have the tendency to form a complex with proteins and minerals, preventing the proper absorption of these nutrients. It has been demonstrated that the extrusion process considerably reduces the amounts of tannins in different pulses such as faba bean, pea, chickpea, and kidney bean, and that with higher processing temperatures and moistures, the reduction in tannins is greater $[61,145]$. The reduction in tannins may occur by alteration of their molecular structure or by changes in their chemical reactivity during extrusion processing. Also, it has been proposed that a reduction in tannins may occur during processing due to an increase in tannin polymerization, which may lead to a reduction in their extractability [62,77].

The effects of the extrusion process on the inactivation of the enzyme inhibitors trypsin, chymotrypsin, and $\alpha$-amylase (Table 6), partially or totally, have been well established by Alonso et al. [77] in pea and bean flours extruded at a barrel temperature of $150{ }^{\circ} \mathrm{C}$, speed screw of $100 \mathrm{rpm}$ and feed moisture of $25 \%$. Morales et al. [12] also reported similar findings in different lentil-based flour formulations extruded at a die temperature of $160^{\circ} \mathrm{C}$, speed screw of $500 \mathrm{rpm}$ and feed moisture of $17 \%$. Moreover, the results of a study carried out by Arribas et al. [82] also corroborate the previously reported findings. They extruded a mixture of rice flour enriched with bean and carob flours or pea and carob flours, processed under the following conditions: barrel temperature of $125^{\circ} \mathrm{C}$, screw speed of $900-950 \mathrm{rpm}$ and feed moisture of $10 \%$. Under these extrusion conditions, the protease inhibitors were fully inactivated. The decrease in enzyme/protease inhibitors may be due to their heatsensitive nature, which in combination with low extrusion moisture promoted the total elimination of these compounds. Morales et al. [12] indicated that the limited elimination of trypsin inhibitors, observed in some cases, could be due to the presence of SH-SH bonds in these enzyme inhibitors and to the crystallized starches formed, acting as protectors.

Table 6. Effect of extrusion process on some antinutrients (enzyme inhibitor and hemagglutinins) of different pulses.

\begin{tabular}{|c|c|c|c|c|c|c|c|c|c|c|}
\hline \multirow{3}{*}{$\begin{array}{l}\text { Food } \\
\text { Matrix }\end{array}$} & \multirow{3}{*}{$\begin{array}{l}\text { Extrusion } \\
\text { Conditions }\end{array}$} & \multicolumn{8}{|c|}{ Effect of the Extrusion Process } & \multirow{3}{*}{ References } \\
\hline & & \multicolumn{2}{|c|}{ TIA } & \multicolumn{2}{|c|}{ CIA } & \multicolumn{2}{|c|}{$\alpha$-AIA } & \multicolumn{2}{|c|}{ HA } & \\
\hline & & NE & E & NE & E & NE & E & NE & E & \\
\hline $\begin{array}{l}\text { Vicia faba } \\
\text { L. }\end{array}$ & $\begin{array}{l}\text { Twin; ss: } 100 \\
\text { rpm; m: } 25 \% \text {; } \\
\text { bt: } 152{ }^{\circ} \mathrm{C}\end{array}$ & $\begin{array}{c}4.47 \pm \\
0.21\end{array}$ & $\begin{array}{c}0.05 \pm \\
0.01\end{array}$ & $\begin{array}{c}3.56 \pm \\
0.16\end{array}$ & $\begin{array}{c}1.68 \pm \\
0.19\end{array}$ & $\begin{array}{c}18.9 \pm \\
1.80\end{array}$ & $\begin{array}{c}0.00 \pm \\
0.00\end{array}$ & $\begin{array}{c}49.3 \pm \\
0.00\end{array}$ & $\begin{array}{c}0.2 \pm \\
0.00\end{array}$ & \\
\hline $\begin{array}{l}\text { Phaseolus } \\
\text { vulgaris L. }\end{array}$ & $\begin{array}{l}\text { Twin; ss: } 100 \\
\text { rpm; m: } 25 \% \text {; } \\
\text { bt: } 156^{\circ} \mathrm{C}\end{array}$ & $\begin{array}{c}3.10 \pm \\
0.24\end{array}$ & $\begin{array}{c}0.43 \pm \\
0.11\end{array}$ & $\begin{array}{c}3.97 \pm \\
0.16\end{array}$ & $\begin{array}{c}0.00 \pm \\
0.00\end{array}$ & $\begin{array}{c}248 \pm \\
4.25\end{array}$ & $\begin{array}{c}0.00 \pm \\
0.00\end{array}$ & $\begin{array}{c}74.5 \pm \\
0.00\end{array}$ & $\begin{array}{c}0.2 \pm \\
0.00\end{array}$ & [145] \\
\hline $\begin{array}{l}\text { Phaseolus } \\
\text { vulgaris L. } \\
\text { Pontal }\end{array}$ & $\begin{array}{l}\text { Single; cr: } 3: 1 ; \\
\text { ss: } 150 \text { rpm; } \\
\text { bt: } 150{ }^{\circ} \mathrm{C} \\
\text { m: } 20 \%\end{array}$ & $\begin{array}{c}4.64 \pm \\
0.03\end{array}$ & $\begin{array}{c}1.36 \pm \\
0.12\end{array}$ & - & - & $\begin{array}{c}18.16 \pm \\
2.98\end{array}$ & ND & Presence & Absence & {$[63]$} \\
\hline $\begin{array}{l}\text { Phaseolus } \\
\text { vulgaris L. } \\
\text { Grafite }\end{array}$ & $\begin{array}{l}\text { Single; cr: } 3: 1 ; \\
\text { ss: } 150 \text { rpm; } \\
\text { bt: } 150{ }^{\circ} \mathrm{C} \\
\text { m: } 20 \%\end{array}$ & $\begin{array}{c}4.61 \pm \\
0.21\end{array}$ & $\begin{array}{c}1.41 \pm \\
0.06\end{array}$ & - & - & $\begin{array}{c}16.08 \pm \\
1.06\end{array}$ & ND & Presence & Absence & {$[00]$} \\
\hline $\begin{array}{l}\text { Lentil } \\
\text { (Lens } \\
\text { culinaris } \\
\text { L. Medik) }\end{array}$ & $\begin{array}{l}\text { Twin; ss: } 500 \\
\text { rpm; } \\
\text { bt: } 160^{\circ} \mathrm{C} ; \\
\text { m: } 17 \%\end{array}$ & $\begin{array}{c}11.43 \pm \\
0.52\end{array}$ & $\begin{array}{c}0.36 \pm \\
0.02\end{array}$ & - & - & - & - & $\begin{array}{c}1.36 \pm \\
0.14\end{array}$ & $\begin{array}{c}0.0 \pm \\
0.00\end{array}$ & \\
\hline $\begin{array}{c}\text { Lentil } \\
\text { (Lens } \\
\text { culinaris } \\
\text { L.)+ } \\
\text { apple } \\
\text { fibre+ } \\
\text { corn fibre }\end{array}$ & $\begin{array}{l}\text { Twin; ss: } 500 \\
\text { rpm; } \\
\text { bt: } 160{ }^{\circ} \mathrm{C} ; \\
\text { m: } 17 \%\end{array}$ & $\begin{array}{c}3.51 \pm \\
0.07\end{array}$ & $\begin{array}{c}0.08 \pm \\
0.00\end{array}$ & - & - & - & - & $\begin{array}{c}0.67 \pm \\
0.13\end{array}$ & $\begin{array}{c}0.0 \pm \\
0.00\end{array}$ & [12] \\
\hline
\end{tabular}


Table 6. Cont.

\begin{tabular}{|c|c|c|c|c|c|c|c|c|c|c|}
\hline \multirow{3}{*}{$\begin{array}{l}\text { Food } \\
\text { Matrix }\end{array}$} & \multirow{3}{*}{$\begin{array}{l}\text { Extrusion } \\
\text { Conditions }\end{array}$} & \multicolumn{8}{|c|}{ Effect of the Extrusion Process } & \multirow{3}{*}{ References } \\
\hline & & \multicolumn{2}{|c|}{ TIA } & \multicolumn{2}{|c|}{ CIA } & \multicolumn{2}{|c|}{$\alpha$-AIA } & \multicolumn{2}{|c|}{ HA } & \\
\hline & & NE & $\mathrm{E}$ & NE & E & NE & E & NE & E & \\
\hline $\begin{array}{c}\text { Rice } \\
(80 \%)+ \\
\text { pea } \\
(\text { Pisum } \\
\text { sativum } \\
\text { L }(20 \%) \text { ) }\end{array}$ & $\begin{array}{c}\text { Twin; ss: } 900 \\
\text { rpm; } \\
\text { bt: } 125^{\circ} \mathrm{C} ; \\
\text { m: } 2.50 \mathrm{~kg} / \mathrm{h}\end{array}$ & 1.33 & n.d. & 1.32 & n.d. & - & - & 20.41 & 0.63 & \\
\hline $\begin{array}{c}\text { Rice } \\
(60 \%)+ \\
\text { pea } \\
(\text { Pisum } \\
\text { sativum } \\
\text { L.) }(40 \%)\end{array}$ & $\begin{array}{c}\text { Twin; ss: } 950 \\
\text { rpm; } \\
\text { bt: } 125^{\circ} \mathrm{C} ; \\
\text { m: } 2.50 \mathrm{~kg} / \mathrm{h}\end{array}$ & 3.11 & n.d. & 3.04 & n.d. & - & - & 20.41 & 5.13 & [82] \\
\hline $\begin{array}{c}\text { Rice } \\
(80 \%)+ \\
\text { bean } \\
\text { (Pisum } \\
\text { vulgaris } \\
\text { L.) }(20 \%)\end{array}$ & $\begin{array}{c}\text { Twin; ss: } 900 \\
\text { rpm; } \\
\text { bt: } 125^{\circ} \mathrm{C} ; \\
\text { m: } 2.50 \mathrm{~kg} / \mathrm{h}\end{array}$ & $\begin{array}{c}4.10 \pm \\
0.09\end{array}$ & n.d. & $\begin{array}{c}1.97 \pm \\
0.09\end{array}$ & n.d. & - & - & - & - & \\
\hline $\begin{array}{l}\text { Rice } \\
(60 \%)+ \\
\text { bean } \\
\text { (Pisum } \\
\text { vulgaris } \\
\text { L.) }(40 \%)\end{array}$ & $\begin{array}{c}\text { Twin; ss: } 950 \\
\text { rpm; } \\
\text { bt: } 125^{\circ} \mathrm{C} ; \\
\text { m: } 2.50 \mathrm{~kg} / \mathrm{h}\end{array}$ & $\begin{array}{c}7.83 \pm \\
0.11\end{array}$ & n.d. & $\begin{array}{c}5.65 \pm \\
0.17\end{array}$ & n.d. & - & - & - & - & [43] \\
\hline
\end{tabular}

TIA: trypsin inhibitor activity (TIU/mg dw); CIA: chymotrypsin inhibitor activity (CIU/mg dw); $\alpha$-AIA: $\alpha$-amylase inhibitor activity (IU/100 g; IU/g dw); HA: haemagglutinating activity; NE: non extruded; E: extruded; twin or single: type of screw; ss: screw speed; bt: barrel temperature; m: moisture; cr: compression ratio; n.d.: not detected.

All of the presented studies provide evidence that extrusion processing promoted the production of products without or with reduced amounts of inositol hexaphosphate (IP6), tannins and enzyme inhibitors, avoiding the undesirable effects of these compounds. While it also maintained or increased the amounts of the less phosphorylated forms of phytic acid, IP5 and IP4, improving the beneficial effects and the nutritional value of the developed products $[66,146]$. Further studies on the sensory properties (texture, colour, and flavour) of extruded pulse products should be considered, as the success of those products rely on consumer's acceptance [43].

\section{Conclusions}

Extrusion is a continuous process that combines different unit operations, including mixing, baking, kneading, shear, moulding and forming. The heat transfer to the food material during processing has an impact on the extent of the physicochemical changes and the quality of the final extruded products. Therefore, the scale-independent measure of mechanical energy, known as specific mechanical energy (SME), is considered a relevant system parameter used to control the extrusion processing operations, which has a great impact in the preservation of valuable amounts of macro and micronutrients (watersoluble vitamins) in the extrudates. It also may impact the preservation of bioactive compounds such as polyphenols, dietary fibre and alpha-galactosides. Other benefits of extrusion processing include the increase in protein and starch digestibility, inactivation of undesirable enzyme inhibitors, as well as a reduction in the amount of inositol phosphates and tannins in pulses and other food materials. 
This review showed that extrusion processing, under different processing conditions, induces chemical and physical changes that favour the bioavailability of important nutrients, and bioactive compounds in pulses and pulse-based extruded flours.

Author Contributions: Investigation, E.N.V., M.C.-S.; writing-original draft preparation, E.N.V., M.C.-S.; writing—review and editing, E.N.V., M.C.-S., H.A.M., J.D.J.B., P.M., V.F.-R., M.C.; supervision, J.D.J.B., P.M., V.F.-R., M.C.; funding acquisition, J.D.J.B., M.C. All authors have read and agreed to the published version of the manuscript.

Funding: This research was funded by UCM-ALIMNOVA Research Group, ref: 951505 and Project OTRI Art. 83 ref: 317-2020, UCM-Fundación Sabor y Salud. Mario Cotapallapa-Sucapuca is grateful to his PhD grant PRONABEC (Peru) no 307541.

Conflicts of Interest: The authors declare no conflict of interest.

\section{References}

1. Berk, Z. Extrusion. In Food Process Engineering and Technology, 3rd ed.; Berk, Z., Ed.; Academic Press: Cambridge, MA, USA, 2018; pp. 373-394. [CrossRef]

2. Rauwendaal, C. Extrusion machinery. In Understanding Extrusion, 3rd ed.; Diaz-Luque, J., Ed.; Hanser Publisher: Munich, Germany, 2019; pp. 1-18. [CrossRef]

3. Berrios, J.D.J.; Morales, P.; Cámara, M.; Sánchez-Mata, M.C. Carbohydrate composition of raw and extruded pulse flours. Food Res. Int. 2010, 43, 531-536. [CrossRef]

4. Emin, M.A. Extrusion. In Reference Module in Food Science; Smithers, G.W., Ed.; Elsiever: Amsterdam, The Netherlands, 2016. [CrossRef]

5. Rosentrater, K.A.; Evers, A.D. Extrusion processing of pasta and other products. In Kent's, Technology of Cereals, 5th ed.; Rosentrater, K.A., Evers, A.D., Eds.; Elsiever: Amsterdam, The Netherlands, 2018; pp. 675-689. [CrossRef]

6. Kristiawan, M.; Della Valle, G.; Kansou, K.; Ndiaye, A.; Vergnes, B. Validation and use for product optimization of a phenomenological model of starch foods expansion by extrusion. J. Food Eng. 2019, 246, 160-178. [CrossRef]

7. Fellows, P.J. Extrusion cooking. In Food Processing Technology, 3rd ed.; Fellows, P.J., Ed.; Woodhead Publishing: Cambridge, UK, 2017; pp. 753-780. [CrossRef]

8. Yang, W.; Zheng, Y.; Sun, W.; Chen, S.; Liu, D.; Zhang, H.; Fang, H.; Tian, J.; Ye, X. Effect of extrusion processing on the microstructure and in vitro digestibility of broken rice. LWT 2020, 119, 108835. [CrossRef]

9. Riaz, M.N. Food extruders. In Handbook of Farm, Dairy and Food Machinery Engineering, 2nd ed.; Kutz, M., Ed.; Elsiever: Amsterdam, The Netherlands, 2019; pp. 483-497. [CrossRef]

10. Arribas, C.; Cabellos, B.; Cuadrado, C.; Guillamón, E.; Pedrosa, M.M. Extrusion effect on proximate composition, starch and dietary fibre of ready-to-eat products based on rice fortified with carob fruit and bean. LWT 2019, 111, 387-393. [CrossRef]

11. Kantrong, H.; Charunuch, C.; Limsangouan, N.; Pengpinit, W. Influence of process parameters on physical properties and specific mechanical energy of healthy mushroom-rice snacks and optimization of extrusion process parameters using response surface methodology. J. Food Sci. Technol. 2018, 55, 3462-3472. [CrossRef]

12. Morales, P.; Berrios, J.D.J.; Varela, A.; Burbano, C.; Cuadrado, C.; Muzquiz, M.; Pedroza, M.M. Novel fiber-rich lentil flours as snack-type functional foods: An extrusion cooking effect on bioactive compounds. Food Funct. 2015, 6, 3135-3143. [CrossRef]

13. Muthukumarappan, K.; Swamy, G.J. Microstructure and its relationship with quality and storage stability of extruded products. In Food Microstructure and Its Relationship with Quality and Stability; Devahastin, S., Ed.; Elsiever: Amsterdam, The Netherlands, 2018; pp. 161-191. [CrossRef]

14. Van der Sman, R.G.M.; Broeze, J. Structuring of indirectly expanded snacks based on potato ingredients: A review. J. Food. Eng. 2013, 114, 413-425. [CrossRef]

15. FAO. Pulses and Derived Products. In Definition and Classification of Commodities; FAO: Rome, Italy, 1994; Available online: http:/ / www.fao.org/es/faodef/fdef04e.ht (accessed on 19 November 2019).

16. FAO. 2050: A Third More Mouths to Feed. 2009. Available online: http://www.fao.org/news/story/en/item/35571/icode/ (accessed on 30 March 2021).

17. Aune, D.; Ursin, G.; Veierød, M.B. Meat consumption and the risk of type 2 diabetes: A systematic review and meta-analysis of cohort studies. Diabetologia 2009, 52, 77-87. [CrossRef]

18. Babio, N.; Sorlı, M.; Bulló, M.; Basora, J.; Ibarrola-Jurado, N.; Fernández-Ballart, J.; Martínez-González, M.A.; Serra-Majem, L.; González-Pérez, R.; Salas-Salvadó, J. Association between red meat consumption and metabolic syndrome in a Mediterranean population at high cardiovascular risk: Cross-sectional and 1-year follow-up assessment. Nutr. Metab. Cardiovasc. Dis. 2012, 22, 200-207. [CrossRef]

19. Song, Y.; Manson, J.E.; Buring, J.E.; Liu, S. A prospective study of red meat consumption and type 2 diabetes in middle-age and elderly women: The women's health study. Diabetes Care 2004, 27, 8-15. [CrossRef]

20. Tzoulaki, I.; Brown, I.J.; Chan, Q.; Van Horn, L.; Ueshima, H.; Zhao, L. Relation of iron and red meat intake to blood pressure: Cross sectional epidemiological study. Br. Med. J. 2008, 15, 37-58. [CrossRef] 
21. FAO. International Year of Pulses Website; FAO: Rome, Italy, 2016; Available online: http:/ /www.fao.org/pulses-2016/en/ (accessed on 10 May 2020).

22. EFSA. Food-Based Dietary Guidelines in Europe. 2019. Available online: https://ec.europa.eu/jrc/en/health-knowledgegateway/promotion-prevention/nutrition/food-based-dietary-guidelines (accessed on 18 December 2019).

23. AESAN. Informe del Comité Científico de la Agencia Española de Seguridad Alimentaria y Nutrición (AESAN) de Revisión y Actualización de Loas Recomendaciones Dietéticas para la Población Española. 2020. Available online: https://www.aesan.gob.es/AECOSAN/docs/documentos/seguridad_alimentaria/evaluacion_riesgos/informes_comite/ RECOMENDACIONES_DIETETICAS.pdf (accessed on 18 March 2020).

24. USDA-DHHS. Dietary Guidelines for Americans; USDA-DHHS: Washington, DC, USA, 2010. Available online: https:/ / health.gov/ sites/default/files/2020-01/DietaryGuidelines2010.pdf (accessed on 18 December 2019).

25. NHLBI. DASH Eating Plan. 2013. Available online: https://www.nhlbi.nih.gov/health-topics/dash-eating-plan (accessed on 18 December 2019).

26. Campos-Vega, R.; Loarca-Piña, G.; Oomah, B.D. Minor components of pulses and their potential impact on human health. Food Res. Int. 2010, 43, 461-482. [CrossRef]

27. Rebello, C.J.; Greenway, F.L.; Finley, J.W. Whole Grains and Pulses: A Comparison of the Nutritional and Health Benefits. J. Agric. Food Chem. 2014, 62, 7029-7049. [CrossRef]

28. Guillon, F.; Champ, M.J. Carbohydrate fractions of legumes: Uses in human nutrition and potential for health. Br. J. Nutr. 2002, 88, 293-306. [CrossRef]

29. López-martínez, L.X.; Leyva-lópez, N.; Gutiérrez-grijalva, E.P.; Heredia, J.B. Effect of cooking and germination on bioactive compounds in pulses and their health benefits. J. Functl. Foods 2017, 38, 624-634. [CrossRef]

30. FAO. FAOSTAT, Food and Agriculture Organization of the United Nations. 2019. Available online: http://www.fao.org/faostat/ en/\#data/QC (accessed on 18 December 2019).

31. Pasqualone, A.; Costantini, M.; Coldea, T.E.; Summo, C. Use of legumes in extrusion cooking: A review. Foods 2020, 9, 958. [CrossRef]

32. Giraldo-Gómez, G.I.; Rodríguez-Barona, S.; Sanabria-González, N.R. Preparation of instant green banana flour powders by an extrusion process. Powder Technol. 2019, 353, 437-443. [CrossRef]

33. Singh, R.P.; Heldman, D.R. Extrusion processes for foods. In Introduction to Food Engineering, 5th ed.; Singh, R.P., Heldman, D.R., Eds.; Academic Press: Cambridge, MA, USA, 2014; pp. 743-766.

34. Dalbhagat, C.G.; Mahato, D.K.; Mishra, H.N. Effect of extrusion processing on physicochemical, functional and nutritional characteristics of rice and rice-based products: A review. Trends Food Sci. Technol. 2019, 85, 226-240. [CrossRef]

35. Kristiawan, M.; Chaunier, L.; Sandoval, A.J.; Della Valle, G. Extrusion-Cooking and expansion. In Breakfast Cereals and How They Are Made, 3rd ed.; Perdon, A.A., Schonauer, S.L., Poutanen, K.S., Eds.; AACC International Press: Oxford, UK, 2020 ; pp. 141-167.

36. Godavarti, S.; Karwe, M.V. Determination of specific mechanical energy distribution on a twin-screw extruder. J. Agric. Eng. Res. 1997, 67, 277-287. [CrossRef]

37. Feng, Y.; Lee, Y. Effect of specific mechanical energy on in-vitro digestion and physical properties of extruded rice-based snacks. Food Nutr. Sci. 2014, 5, 1818-1827. [CrossRef]

38. Haley, T.A.; Mulvaney, S.J. On-line system identification and control design of an extrusion cooking process: Part I. System identification. Food Control 2000, 11, 103-120. [CrossRef]

39. Kulshreshtha, M.K.; Zaror, C.A.; Jukes, D.J. Automatic control of food extrusion: Problems and perspectives. Food Control 1991, 2, 80-86. [CrossRef]

40. Moya, E.; Becares, J.; Modelado y Simulación de un Proceso de Extrusión. In XXIX Jornadas de Automática, Universitat Rovira i Virgili-Tarragona, Spain. 2008. Available online: http:/ /jata08-events.urv.cat/ (accessed on 13 May 2021).

41. Pardhi, S.D.; Singh, B.; Nayik, G.A.; Dar, B.N. Evaluation of functional properties of extruded snacks developed from brown rice grits by using response surface methodology. J. Saudi Soc. Agric. Sci. 2019, 18, 7-16. [CrossRef]

42. Ciudad-Mulero, M.; Barros, L.; Fernandes, A.; Berrios, J.D.J.; Cámara, M.; Morales, P.; Fernández-Ruiz, V.; Ferreira, I.C.F.R. Bioactive compounds and antioxidant capacity of extruded snack-type products developed from novel formulations of lentil and nutritional yeast flours. Food Funct. 2018, 9, 819-829. [CrossRef]

43. Arribas, C.; Cabellos, B.; Cuadrado, C.; Guillamón, E.; Pedrosa, M.M. Bioactive compounds, antioxidant activity, and sensory analysis of rice-based extruded snacks-like fortified with bean and carob fruit flours. Foods 2019, 8, 381. [CrossRef]

44. Oomah, B.D.; Patras, A.; Rawson, A.; Singh, N.; Campos-Vega, R. Chemistry of Pulses. In Pulse Foods: Processing Quality and Nutraceutical Applications, 1st ed.; Tiwari, B., Gowen, A., McKenna, B., Eds.; Elsevier Ltd.: Ireland, UK, 2011; pp. 9-55. [CrossRef]

45. Duranti, M. Grain legume proteins and nutraceutical properties. Fitoterapia 2006, 77, 67-82. [CrossRef] [PubMed]

46. Roy, F.; Boye, J.I.; Simpson, B.K. Bioactive proteins and peptides in pulse crops: Pea, chickpea and lentil. Food Res. Int. 2010, 43, 432-442. [CrossRef]

47. Hall, C.; Cassandra Hillen, C.; Garden Robinson, J. Composition, nutrition al value, and health benefits of pulses. Rev. Cereal Chem. 2017, 94, 11-31. [CrossRef]

48. Boye, J.; Zare, F.; Pletch, A. Pulse proteins: Processing, characterization, functional properties and applications in food and feed. Food Res. Int. 2010, 43, 414-431. [CrossRef] 
49. Nwokolo, E.; Smartt, J. The need to increase consumption of pulses in the developing world. In Food and Feed from Legume and Oilseeds, 1st ed.; Nwokolo, E., Smartt, J., Eds.; Chapman \& Hall: London, UK, 1996; pp. 4-5.

50. Kim, C.H.; Maga, J.A. Properties of extruded whey protein concentrate and cereal flour blends. LWT 1987, 20, 311-318.

51. Onwulata, C.I.; Konstance, R.P.; Cooke, P.H.; Farrell, H.M. Functionality of Extrusion-Texturized Whey Proteins. J. Dairy Sci. 2003, 86, 3775-3782. [CrossRef]

52. Li, M.; Lee, T. Effect of extrusion temperature on solubility and molecular weight distribution of wheat flour proteins. J. Agric. Food Chem. 1996, 44, 763-768. [CrossRef]

53. Arêas, J.A.G. Extrusion of food proteins. Food Sci. Nutr. 1992, 32, 365-392. [CrossRef]

54. Lopes-da-Silva, M.F.; Santos, L.; Choupina, A. A extrusão em tecnologia alimentar: Aplicações, características dos produtos, composição e tendências futuras. Revista De Ciências Agrárias 2016, 39, 4-14. [CrossRef]

55. Oliver, C.M.; Melton, L.D.; Stanley, R.A. Creating Proteins with Novel Functionality via the Maillard Reaction: A Review. Crit. Rev. Food Sci. Nutr. 2007, 46, 337-350. [CrossRef] [PubMed]

56. Masatcioglu, M.T.; Gokmen, V.; Ng, K.W.; Koksel, H. Effects of formulation, extrusion cooking conditions, and $\mathrm{CO}_{2}$ injection on the formation of acrylamide in corn extrudates. J. Sci. Food Agric. 2014, 94, 2562-2568. [CrossRef]

57. Singh, S.; Gamlath, S.; Wakeling, L. Nutritional aspects of food extrusion: A review. Int. J. Food Sci. Technol. 2007, 42, 916-929. [CrossRef]

58. Friedman, M.; Levin, C. Review of methods for the reduction of dietary content and toxicity of acrylamide. J. Agric. Food Chem. 2008, 56, 6113-6140. [CrossRef]

59. Galani, J.H.Y.; Patel, N.J.; Talati, J.G. Acrylamide-forming potential of cereals, legumes and roots and tubers analyzed by UPLC-UV. Food Chem. Toxicol. 2017, 108, 244-248. [CrossRef]

60. Tuncel, N.B.; Yilmaz, N.; Sener, E. The effect of pea (Pisum sativum L.) originated asparaginase on acrylamide formation in certain bread types. Int. J. Food Sci. Technol. 2010, 45, 2470-2476. [CrossRef]

61. El-Hady, E.A.A.; Habiba, R.A. Effect of soaking and extrusion conditions on antinutrients and protein digestibility of legume seeds. LWT 2003, 36, 285-293. [CrossRef]

62. Patterson, C.A.; Curran, J.; Der, T. Effect of Processing on Antinutrient Compounds in Pulses. Cereal Chem. 2017, 94, 2-9. [CrossRef]

63. Batista, K.A.; Prudencio, S.H.; Fernandes, K.F. Changes in the Functional Properties and Antinutritional Factors of Extruded Hard-to-Cook Common Beans (Phaseolus vulgaris, L.). J. Food Sci. 2010, 75, 286-290. [CrossRef] [PubMed]

64. Nosworthy, M.G.; Medina, G.; Franczyk, A.J.; Neufeld, J.; Appah, P.; Utioh, A.; Frohlich, P.; House, J.D. Effect of processing on the in vitro and in vivo protein quality of beans (Phaseolus vulgaris and Vicia Faba). Nutrients 2018, 10, 671. [CrossRef] [PubMed]

65. Nosworthy, M.G.; Medina, G.; Franczyk, A.J.; Neufeld, J.; Appah, P.; Utioh, A.; Frohlich, P.; House, J.D. Effect of processing on the in vitro and in vivo protein quality of red and green lentils (Lens culinaris). Food Chem. 2018, 240, 588-593. [CrossRef] [PubMed]

66. Rathod, R.P.; Annapure, U.S. Physicochemical properties, protein and starch digestibility of lentil-based noodle prepared by using extrusion processing. LWT 2017, 80, 121-130. [CrossRef]

67. Guldiken, B.; Yovchev, A.; Nosworthy, M.G.; Stone, A.K.; House, J.D.; Hood-Niefer, S.; Nickerson, M.T. Effect of extrusion conditions on the physical properties of desi chickpea-barley extrudates and quality attributes of their resulting flours. J. Texture Stud. 2019, 1-8. [CrossRef]

68. Tharanathan, R.N.; Mahadevamma, S. Grain legumes-A boon to human nutrition. Food Sci. Technol. 2003, 14, 507-518. [CrossRef]

69. Yan, X.; Wu, Z.-Z.; Li, M.-Y.; Yin, F.; Ren, K.-X.; Tao, H. The combined effects of extrusion and heat-moisture treatment on the physicochemical properties and digestibility of corn starch. Int. J. Biol. Macromol. 2019, 134, 1108-1112. [CrossRef]

70. Khlestkin, V.K.; Peltek, S.E.; Kolchanov, N.A. Review of direct chemical and biochemical transformations of starch. Carbohydr. Polym. 2018, 181, 460-476. [CrossRef]

71. Zhu, J.; Zhang, S.; Zhang, B.; Qiao, D.; Pu, H.; Liu, S.; Li, L. Structural features and thermal property of propionylated starches with different amylose/amylopectin ratio. Int. J. Biol. Macromol. 2017, 97, 123-130. [CrossRef] [PubMed]

72. Shevkani, K.; Singh, N.; Rattan, B.; Singh, J.P.; Kaur, A.; Singh, B. Effect of chickpea and spinach on extrusion behavior of corn grit. J. Food Sci. Technol. 2019, 56, 2257-2266. [CrossRef] [PubMed]

73. Maubane, L.; Ray, S.S.; Jalama, K. The effect of starch amylose content on the morphology and properties of melt-processed butyl-etherified starch/poly[(butylene succinate)-co-adipate] blends. Carbohydr. Polym. 2017, 155, 89-100. [CrossRef]

74. Jebalia, I.; Maigret, J.E.; Reguerre, A.L.; Novales, B.; Guessasma, S.; Lourdin, D.; Della Valle, G.; Kristiawan, M. Morphology and mechanical behaviour of pea-based starch-protein composites obtained by extrusion. Carbohydr. Polym. 2019, 223, 115086. [CrossRef]

75. Chaudhary, A.L.; Miler, M.; Torley, P.J.; Sopade, P.A.; Halley, P.J. Amylose content and chemical modification effects on the extrusion of thermoplastic starch from maize. Carbohydr. Polym. 2008, 74, 907-913. [CrossRef]

76. Cardoso-Santiago, R.A.; Arêas, J.A.G. Nutritional evaluation of snacks obtained from chickpea and bovine lung blends. Food Chem. 2001, 74, 35-40. [CrossRef]

77. Alonso, R.; Rubio, L.A.; Muzquiz, M.; Marzo, F. The effect of extrusion cooking on mineral bioavailability in pea and kidney bean seed meals. Anim. Feed Sci. Technol. 2001, 94, 1-13. [CrossRef] 
78. Morales, P.; Cebadera-Miranda, L.; Cámara, R.M.; Reis, F.S.; Barros, L.; Berrios, J.D.J.; Ferreira, I.C.F.R.; Cámara, M. Lentil flour formulations to develop new snack-type products by extrusion processing: Phytochemicals and antioxidant capacity. J. Funct. Foods 2015, 19, 537-544. [CrossRef]

79. Amor, B.B.; Lamy, C.; Andre, P.; Allaf, K. Effect of instant controlled pressure drop treatments on the oligosaccharides extractability and microstructure of Tephrosia purpurea seeds. J. Chromatogr. A 2008, 1213, 118-124. [CrossRef]

80. Pedrosa, M.M.; Cuadrado, C.; Burbano, C.; Allaf, K.; Haddad, J.; Gelencsér, E.; Takács, K.; Guillamón, E.; Muzquiz, M. Effect of instant controlled pressure drop on the oligosaccharides, inositol phosphates, trypsin inhibitors and lectins contents of different legumes. Food Chem. 2012, 131, 862-868. [CrossRef]

81. Berrios, J.D.J.; Camára, M.; Torija, M.E.; Alonso, M. Effect of extrusion cooking and sodium bicarbonate addition on the carbohydrate composition of black bean flours. J. Food Process. Preserv. 2002, 26, 113-128. [CrossRef]

82. Arribas, C.; Cabellos, B.; Cuadrado, C.; Guillamón, E.; Pedrosa, M.M. The effect of extrusion on the bioactive compounds and antioxidant capacity of novel gluten-free expanded products based on carob fruit, pea and rice blends. Innov. Food Sci. Emerg. Technol. 2019, 52, 100-107. [CrossRef]

83. IFST-The Institute of Food Science and Technology. Dietary Fiber; Public Affairs and Technical and Legislative Committees; IFST: London, UK, 2007.

84. Cámara, M.; Fernández-Ruiz, V.; Morales, P.; Sánchez-mata, M.C. Fiber Compounds and Human Health. Curr. Pharm. Des. 2017, 23, 1-15. [CrossRef] [PubMed]

85. Cámara, M.; Sánchez-Mata, M.C.; Morales, P.; De Beirros, J. Legume pulses as a source of functional dietary fibre ingredients. In Seed as Functional Foods and Nutraceuticals: New Frontiers in Food Science; Mora-Escobedo, R., Berrios, J.D.J., Gutierrez-Lopez, G.F., Eds.; Nova Science Publisher: Hauppauge, NY, USA, 2014; pp. 71-91. ISBN 978-1-62808-489-4.

86. Hoover, R.; Hughes, T.; Chung, H.J.; Liu, Q. Composition, molecular structure, properties, and modification of pulse starches: A review. Food Res. Int. 2010, 43, 399-413. [CrossRef]

87. Tiwari, B.K.; Cummins, E. Functional and physicochemical properties of legume fibers. In Pulse Foods: Processing, Quality and Nutraceutical Applications, 1st ed.; Tiwari, B.K., Gowen, A., McKenna, B.M., Eds.; Academic Press: Amsterdam, The Netherlands, 2011; pp. 121-156.

88. Martín-Cabrejas, M.A.; Aguilera, Y.; Benítez, V.; Mollá, E.; López-Andréu, F.J.; Esteban, R.M. Effect of Industrial Dehydration on the Soluble Carbohydrates and Dietary Fiber Fractions in Legumes. J. Agric. Food Chem. 2006, 54, 7652-7657. [CrossRef]

89. Rochfort, S.; Panozzo, J. Phytochemicals for health, the role of pulses. J. Agric. Food Chem. 2007, 55, 7981-7994. [CrossRef]

90. Ciudad-Mulero, M.; Matallana-González, M.C.; Cámara, M.; Fernández-Ruiz, V.; Morales, P. Antioxidant phytochemicals in pulses and their relation to human health: A Review. Curr. Pharm. Des. 2020, 26, 1880-1897. [CrossRef]

91. Esposito, F.; Arlotti, G.; Bonifati, A.M.; Napolitano, A.; Vitale, D.; Fogliano, V. Antioxidant activity and dietary fibre in durum wheat bran by-products. Food Res. Int. 2005, 38, 1167-1173. [CrossRef]

92. Theander, O.; Westerlund, E. Studies on chemical modifications in heat-processed starch and wheat flour. Starch Stärke 1987, 39, 88-93. [CrossRef]

93. Vasanthan, T.; Gaosong, J.; Yeung, J.; Li, J. Dietary fiber profile of barley flour as affected by extrusion cooking. Food Chem. 2002, 77, 35-40. [CrossRef]

94. Delgado-Nieblas, C.I.; Zazueta-Morales, J.J.; Gallegos-Infante, J.A.; Aguilar-Palazuelos, E.; Camacho-Hernández, I.L.; OrdoricaFalomir, C.A.; de Pires Melo, M.; Carrillo-López, A. Elaboration of functional snack foods using raw materials rich in carotenoids and dietary fiber: Effects of extrusion processing. CYTA J. Food 2015, 13, 69-79. [CrossRef]

95. Quirós Sauceda, A.E.; Palafox, H.; Robles Sánchez, R.M.; González Aguilar, G.A. Interacción De Compuestos Fenólicos Y Fibra Dietaria: Capacidad Antioxidante Y Biodisponibilidad. Biotecnia 2012, 13, 3-11. [CrossRef]

96. Larrea, M.A.; Chang, Y.K.; Martínez Bustos, F. Effect of some operational extrusion parameters on the constituents of orange pulp. Food Chem. 2005, 89, 301-308. [CrossRef]

97. Unlu, E.; Faller, J.F. Formation of resistant starch by a twin-screw extruder. Cereal Chem. 1998, 75, 346-350. [CrossRef]

98. Fogliano, V.; Maria Monti, S.; Musella, T.; Randazzo, G.; Ritieni, A. Formation of coloured Maillard reaction products in a gluten-glucose model system. Food Chem. 1999, 66, 293-299. [CrossRef]

99. Stojceska, V.; Ainsworth, P.; Plunkett, A.; Ibanoğlu, Ş. The advantage of using extrusion processing for increasing dietary fibre level in gluten-free products. Food Chem. 2010, 121, 156-164. [CrossRef]

100. Zhang, M.; Bai, X.; Zhang, Z. Extrusion process improves the functionality of soluble dietary fiber in oat bran. J. Cereal Sci. 2011, 54, 98-103. [CrossRef]

101. Jing, Y.; Chi, Y.J. Effects of twin-screw extrusion on soluble dietary fibre and physicochemical properties of soybean residue. Food Chem. 2013, 138, 884-889. [CrossRef]

102. Chen, Y.; Ye, R.; Yin, L.; Zhang, N. Novel blasting extrusion processing improved the physicochemical properties of soluble dietary fiber from soybean residue and in vivo evaluation. J. Food Eng. 2014, 120, 1-8. [CrossRef]

103. Carvalho, A.V.; de Andrade Mattiett, R.; Bassinello, P.Z.; Koakuzu, S.N.; de Oliveira Rios, A.; de Almeida Maciel, R.; Carvalho, R.N. Processing and characterization of extruded breakfast meal formulated with broken rice and bean flour. Food Sci. Technol. 2012, 32, 515-524. [CrossRef]

104. Shih, M.C.; Kuo, C.C.; Chiang, W. Effects of drying and extrusion on colour, chemical composition, antioxidant activities and mitogenic response of spleen lymphocytes of sweet potatoes. Food Chem. 2009, 117, 114-121. [CrossRef] 
105. Oliveira, L.C.; Rosell, C.M.; Steel, C.J. Effect of the addition of whole-grain wheat flour and of extrusion process parameters on dietary fibre content, starch transformation and mechanical properties of a ready-to-eat breakfast cereal. Int. J. Food Sci. Technol. 2015, 50, 1504-1514. [CrossRef]

106. Rashid, S.; Rakha, A.; Anjum, F.M.; Ahmed, W.; Sohail, M. Effects of extrusion cooking on the dietary fibre content and Water Solubility Index of wheat bran extrudates. Int. J. Food Sci. Technol. 2015, 50, 1533-1537. [CrossRef]

107. Huang, Y.L.; Ma, Y.S. The effect of extrusion processing on the physiochemical properties of extruded orange pomace. Food Chem. 2016, 192, 363-369. [CrossRef]

108. Stojceska, V.; Ainsworth, P.; Plunkett, A.; Ibanoğlu, E.; Ibanoğlu, Ş. Cauliflower by-products as a new source of dietary fibre, antioxidants and proteins in cereal based ready-to-eat expanded snacks. J. Food Eng. 2008, 87, 554-563. [CrossRef]

109. Sánchez-Mata, M.C.; Peñuela-Teruel, M.J.; Cámara-Hurtado, M.; Díez-Marqués, C.; Torija-Isasa, M.E. Determination of Mono-, Di-, and Oligosaccharides in Legumes by High-Performance Liquid Chromatography Using an Amino-Bonded Silica Column. J. Agric. Food Chem. 1998, 46, 3648-3652. [CrossRef]

110. Nikmaram, N.; Leong, S.Y.; Koubaa, M.; Zhu, Z.; Barba, F.J.; Greiner, R.; Oey, I.; Roohinejad, S. Effect of extrusion on the anti-nutritional factors of food products: An overview. Food Control 2017, 79, 62-73. [CrossRef]

111. Van Loo, J.; Cummings, J.; Delzenne, N.; Englyst, H.; Franck, A.; Hopkins, M.; Kok, N.; Macfarlane, G.; Newton, D.; Quigley, M.; et al. Functional food properties of non-digestible oligosaccharides: A consensus report from the ENDO project (DGXII AIRII-CT94-1095). Br. J. Nutr. 1999, 81, 121-132. [CrossRef]

112. Frias, J.; Giacomino, S.; Peñas, E.; Pellegrino, N.; Ferreyra, V.; Apro, N.; Olivera, M.C.; Vidal-Valverde, C. Assessment of the nutritional quality of raw and extruded Pisum sativum L. var. laguna seeds. LWT Food Sci. Technol. 2011, 44, 1303-1308. [CrossRef]

113. Riaz, M.N.; Asif, M.; Ali, R. Stability of vitamins during extrusion. Crit. Rev. Food Sci. Nutr. 2009, 49, 361-368. [CrossRef]

114. Zielinski, H.; Kozlowska, H.; Lewczuk, B. Bioactive compounds in the cereal grains before and after hydrothermal processing. Innov. Food Sci. Emerg. Technol. 2001, 2, 159-169. [CrossRef]

115. Athar, N.; Hardacre, A.; Taylor, G.; Clark, S.; Harding, R.; McLaughlin, J. Vitamin retention in extruded food products. J. Food Compos. Anal. 2006, 19, 379-383. [CrossRef]

116. Camire, M.E.; Camire, A.; Krumhar, K. Chemical and nutritional changes in foods during extrusion. Crit. Rev. Food Sci. Nutr. 1990, 29, 35-57. [CrossRef]

117. Brennan, C.; Brennan, M.; Derbyshire, E.; Tiwari, B.K. Effects of extrusion on the polyphenols, vitamins and antioxidant activity of foods. Trends Food Sci. Technol. 2011, 22, 570-575. [CrossRef]

118. Gulati, P.; Rose, D.J. Effect of extrusion on folic acid concentration and mineral element dialyzability in Great Northern beans (Phaseolus vulgaris L.). Food Chem. 2018, 269, 118-124. [CrossRef]

119. Bouchenak, M.; Lamri-senhadji, M. Nutritional Quality of Legumes, and Their Role in Cardiometabolic Risk Prevention: A Review. J. Med. Food 2013, 16, 1-14. [CrossRef]

120. Kalogeropoulos, N.; Chiou, A.; Ioannou, M.; Karathanos, V.T.; Hassapidou, M.; Andrikopoulos, N.K. Nutritional evaluation and bioactive microconstituents (phytosterols, tocopherols, polyphenols, triterpenic acids) in cooked dry legumes usually consumed in the Mediterranean countries. Food Chem. 2010, 121, 682-690. [CrossRef]

121. Padhi, E.M.T.; Ramdath, D.D. A review of the relationship between pulse consumption and reduction of cardiovascular disease risk factors. J. Funct. Foods 2017, 38, 635-643. [CrossRef]

122. Rodrigo, R.; Prat, H.; Passaiacqua, W.; Araya, J.; Bächler, J.P. Decrease in oxidative stress through supplementation of vitamins $\mathrm{C}$ and $\mathrm{E}$ is associated with a reduction in blood pressure in patient with essential hypertension. Clin. Sci. 2008, 114, 625-634. [CrossRef]

123. Zemestani, M.; Rafraf, M.; Ashgari-Jafarabadi, M. Chamomile tea improves glycemic indices and antioxidant status in patients with type 2 diabetes mellitus. Nutrition 2016, 32, 66-72. [CrossRef]

124. Ciudad-Mulero, M.; Fernández-Ruiz, V.; Matallana-González, M.C.; Morales, P. Dietary fiber sources and human benefits: The case study of cereal and pseudocereals. In Advances in Food and Nutrition Research, 1st ed.; Ferreira, I.C.F.R., Barros, L., Eds.; Elsiever: Amsterdam, The Netherlands, 2019; Volume 90, pp. 83-134. [CrossRef]

125. Xu, B.J.; Chang, S.K.C. A Comparative Study on Phenolic Profiles and Antioxidant Activities of Legumes as Affected by Extraction Solvent. J. Food Sci. 2007, 72, 159-166. [CrossRef]

126. Mahungu, S.M.; Diaz-Mercado, S.; Li, J.; Schwenk, M.; Singletary, K.; Faller, J. Stability of isoflavones during extraction processing of soy/corn mixture. J. Agric. Food Chem. 1999, 47, 279-284. [CrossRef] [PubMed]

127. Yağci, S.; Gögüş, F. Effect of incorporation of various food by-products on some nutritional properties of rice-based extruded foods. Food Sci. Technol. Int. 2009, 15, 571-581. [CrossRef]

128. Altan, A.; Mccarthy, K.L.; Maskan, M. Effect of extrusion process on antioxidant activity, total phenolics and b-glucan content of extrudates developed from barley-fruit and vegetable by-products. Int. J. Food Sci. Technol. 2009, 44, 1263-1271. [CrossRef]

129. Wang, T.; He, F.; Chen, G. Improving bioaccessibility and bioavailability of phenolic compounds in cereal grains through processing technologies: A concise review. J. Funct. Foods 2014, 7, 101-111. [CrossRef]

130. Anton, A.A.; Fulcher, R.G.; Arntfield, S.D. Physical and nutritional impact of fortification of corn starch-based extruded snacks with common bean (Phaseolus vulgaris L.) flour: Effects of bean addition and extrusion cooking. Food Chem. 2009, 113, 989-996. [CrossRef] 
131. Awika, J.M.; Dykes, L.; Gu, L.W.; Rooney, L.W.; Prior, R.L. Processing of sorghum (Sorghum bicolor) and sorghum products alters procyanidin oligomer and polymer distribution and content. J. Agric. Food Chem. 2003, 51, 5516-5521. [CrossRef] [PubMed]

132. Nayak, B.; Liu, R.H.; Tang, J. Effect of Processing on Phenolic Antioxidants of Fruits, Vegetables, and Grains-A Review. Food Sci. Nutr. 2015, 55, 887-918. [CrossRef] [PubMed]

133. Sensoy, I.; Rosen, R.T.; Ho, C.; Karwe, M.V. Effect of processing on buckwheat phenolics and antioxidant activity. Food Chem. 2006, 99, 388-393. [CrossRef]

134. Korus, J.; Gumul, D.; Czechowska, K. Effect of extrusion on the phenolic composition and antioxidant activity of dry beans of Phaseolus vulgaris L. Food Technol. Biotech. 2007, 45, 139-146.

135. Champ, M.M. Non-nutrient bioactive substances of pulses. Br. J. Nutr. 2002, 88, S307-S319. [CrossRef] [PubMed]

136. Duranti, M.; Gius, C. Legume seeds: Protein content and nutritional value. J. Field Crop. Res. 1997, 53, 31-45. [CrossRef]

137. Muzquiz, M.; Varela, A.; Burbano, C.; Cuadrado, C.; Guillamón, E.; Pedrosa, M.M. Bioactive compounds in legumes: Pronutritive and antinutritive actions. Implications for nutrition and health. Phytochem. Rev. 2012, 11, 227-244. [CrossRef]

138. Udahogora, M. Health benefits and bioactive compounds in field peas, faba beans, and chickpeas. In Cereals and Pulses: Nutraceutical Properties and Health Benefits, 1st ed.; Yu, L., Tsao, R., Shahidi, F., Eds.; John Wiley \& Sons: Hoboken, NJ, USA, 2012; pp. 199-215.

139. Wang, H.X.; Ng, T.B. An antifungical peptide from red lentil seeds. Peptides 2007, 28, 547-552. [CrossRef]

140. Ye, X.Y.; $\mathrm{Ng}$, T.B. Isolation of a new cyclophilin-like protein from chickpeas with mitogenic, antifungical and anti-HIV-1 reverse transcriptase activities. J. Life Sci. 2002, 70, 1129-1138. [CrossRef]

141. Reddy, B.S. Possible Mechanisms by which pro- and prebiotics influence colon carcinogenesis and tumor growth. J. Nutr. 1999, 129, 1478-1482. [CrossRef] [PubMed]

142. Sidhu, G.S.; Oakenfull, D.G. A mechanism for the hypocholesterolaemic activity of saponins. Br. J. Nutr. 1986, 55, 643-649. [CrossRef]

143. Thompson, L.U. Potential health benefits and problems associated with antinutrients in foods. Food Res. Int. 1993, 26, 131-149. [CrossRef]

144. Martínez, C.; Ros, G.; Periago, M.J.; López, G.; Ortuño, J.; Rincón, F. Phytic acid in human nutrition. Food Sci. Technol. Int. 1996, 2, 201-209. [CrossRef]

145. Alonso, R.; Aguirre, A.; Marzo, F. Effects of extrusion and traditional processing methods on antinutrients and in vitro digestibility of protein and starch in faba and kidney beans. Food Chem. 2000, 68, 159-165. [CrossRef]

146. Sparvoli, F.; Laureati, M.; Pilu, R.; Pagliarini, E.; Toschi, I.; Giuberti, G.; Fortunati, P.; Daminati, M.G.; Cominelli, E.; Bollini, R. Exploitation of common bean flours with low antinutrient content for making nutritionally enhanced biscuits. Front. Plant Sci. 2016, 7, 1-14. [CrossRef] [PubMed] 